\title{
Os índios de Pedra Branca-Bahia (1825-1889): uma história de conflitos e resistência em defesa da terra indígena
}

\author{
The Indigenous peoples of Pedra Branca-Bahia (1825-1889): a history of conflicts and \\ resistance in defense of indigenous land
}

Edilmar Cardoso Ribeiro ${ }^{1}$

\begin{abstract}
Resumo
A história da vila (municipalidade) e depois aldeamento de Pedra Branca (1822-1890), atual povoado de Pedra Branca, localizado no município de Santa Teresinha-Bahia, foi marcada por conflitos entre indígenas, autoridades públicas e colonos locais. Os indígenas de Pedra Branca fizeram frente ao processo de exclusão da participação da administração pública da vila e, principalmente, ao processo de usurpação das terras indígenas, isto é, de uma légua e meia de terra que os indígenas diziam terem herdado dos seus antepassados e, por isso, de serem seus legítimos donos. Os indígenas resistiram a esse processo ocupando cargos de vereadores e juízes (por meio dos quais podiam controlar a administração da terra indígena e garantir a posse dela), negociando com autoridades não indígenas ou se insubordinando perante elas e, em extremo caso, montando revoltas armadas As medidas das autoridades públicas não indígenas (vereadores, diretores de índios, delegados, juízes, militares, vigários, missionários) para controlar e enquadrar os indígenas dentro de sua ordem foram negociações, a implementação da diretoria dos índios, o direcionamento dos missionários e expedições militares. O resultado desse processo conflituoso foi a extinção da municipalidade e do aldeamento, a invasão das terras por posseiros e a dispersão dos indígenas.
\end{abstract}

Palavras-chave: Índios; Pedra Branca; Aldeamento; Terras indígenas

\begin{abstract}
The history of the municipality and later aldeamento of Pedra Branca (1822-1890), present-day village of Pedra Branca, located in Santa Teresinha-Bahia, was marked by conflicts between indigenous peoples, public authorities and local settlers. The indigenous peoples of Pedra Branca were faced with the process of exclusion from the participation of the public administration of the village and, mainly, the process of usurpation of the indigenous lands, that is, a league and a half of land that natives said they had inherited from their ancestors and, therefore, rightfully owners. Indigenous forms of resistance to this process: occupying the positions of councilors and judges as a means of controlling the administration of indigenous land and securing their possession, negotiations with non-indigenous authorities, insubordination to constituted non-indigenous authorities, and riots. The measures of non-indigenous public authorities (councilors, Native directors, delegates, judges, military, vicars, missionaries) to control and frame indigenous peoples within their order: negotiations, the indigenous, the Missionary Director, and military expeditions. The result of this conflictuos process was: the extinction of the municipality and the settlement, the invasion of land by squatters and the dispersal of indigenous peoples.
\end{abstract}

Keywords: indigenous peoples; Pedra Branca; aldeamento; Indigenous lands

\footnotetext{
${ }^{1}$ Doutor em História da Igreja pela Pontifícia Universidade Gregoriana (Itália). Professor Titular da Universidade Católica de Salvador (Brasil). E-mail: edillcardoso@hotmail.com
} 


\section{Introdução}

A partir da emancipação política brasileira ocorrida em 1822, a questão indígena foi bastante discutida, sobretudo no que diz respeito à mão-de-obra e à formação da identidade nacional. Nesse contexto, predominaram dois modos de pensar que informavam as práticas no trato com os indígenas. Um, que se pode denominar de filantrópico ou assimilacionista, acreditava na possibilidade de 'civilizar' os povos nativos através dos aldeamentos e da catequese; o outro desconsiderava essa possibilidade e, portanto, seus meios, propondo em seu lugar o trabalho forçado e a tomada forçosa das terras indígenas (MONTEIRO, 2001). No entanto, durante o século XIX prevaleceu, pelo menos no discurso oficial, a "corrente" assimilacionista, vendo ainda no aldeamento e na catequese religiosa os meios mais eficazes para amansar e civilizar os índios "bravios", embora as práticas violentas não deixassem de existir completamente.

A emancipação política nacional não significou a emancipação dos povos indígenas, assim como não resultou em uma legislação indigenista clara. Por falta desta clareza e pelo processo de expansão da colonização do interior, colocou-se em processo, cada vez mais acentuado, a usurpação das terras indígenas e, de consequência, a dispersão dos índios das vilas e aldeamentos, cuja usurpação buscou-se justificar na não existência de índios nas antigas vilas e aldeamentos, por terem sidos extintos ou por terem sidos assimilados e, portanto, a não haver mais necessidade de um regime especial para os índios e de manter os antigos aldeamentos (PARAÍSO, 1998, p. 462).

Este artigo tem como objetivo construir as relações conflituosas entre indígenas, as autoridades diversas (diretor dos índios, ouvidores, juízes, delegados e militares) e moradores, que viviam dentro ou no entorno do núcleo da municipalidade e depois aldeamento de Pedra Branca (hoje povoado Pedra Branca, localizado no município de Santa Teresinha-Ba.), entre 1825 e 1889, mostrando as estratégias de resistência dos indígenas, que geralmente recorriam à revolta e à desobediência às autoridades locais como único meio para defender seus bens, principalmente "uma légua em quadro" de terra, cuja terra os indígenas alegavam ser herança deixada por seus antepassados, assim como mostrando as iniciativas das várias autoridades locais e provincial para submeter à sua ordem os revoltosos e desobedientes indígenas.

Para tanto, este trabalho utiliza-se essencialmente de fontes primárias, que são correspondências (manuscritas) encontradas no Arquivo Público do Estado da Bahia 
(APEB) e no Arquivo histórico de Nossa Senhora da Piedade (AHNSP), em Salvador. Quase todas estas correspondências são das autoridades públicas constituídas, mas a abordagem que fazemos dessas fontes é a que tem se consolidado nas últimas décadas com a história social, ${ }^{2}$ isto é, que procura colocar os indígenas como atores ativos da história do Brasil, vendo até mesmo no fato de fugir para as matas como uma atitude ativa e de resistência.

\section{Disputas pelo governo da municipalidade de Pedra Branca e controle e posse das terras}

A vila de Pedra Branca surgiu de um antigo aldeamento de índios kiriri-sapuiá, ${ }^{3}$ cuja municipalidade foi instituída em torno a 1761, a partir da reforma do Diretório dos Índios do Marquês de Pombal (1750), com o nome de Nossa Senhora de Nazaré de Pedra Branca (SANTOS, 2012, p. 184-189), hoje povoado de Pedra Branca, no município de Santa Teresinha, situado na região centro-oeste do Estado da Bahia. Até 1835, quando foi extinta municipalidade, a vila foi regida pela Câmara Municipal (OLIVEIRA, 9 de jul. 1830. APEB, Seção Colonial/Provincial, Maço 1376; MAPA DO MUNICÍPIO DE TAPERA, 1872. APEB, Seção Colonial/Provincial, Maço 1445).

Para compreender a supressão da municipalidade de Pedra Branca em 1835, temos que entrar no âmbito das relações entre indígenas, autoridades públicas locais e colonos. Já em 1825, temos representações sobre grupo de índios que entravam na vila armados para protestar contra as autoridades constituídas (CÂMARA MUNICIPAL DA VILA DE NAZARÉ, 30 de abr. 1825. APEB, Seção Colonial/Provincial, Maço 1376). Em 1828, a Câmara Municipal quis nomear o capitão-mor e os índios se opuseram à nomeação de um que não fosse índio. A Câmara alegava que entre os índios não havia um que tivesse os requisitos, segundo a lei, para ser nomeado. Então, o corregedor deu a ordem para que se nomeasse um índio e um brasileiro, isto é, não índio, para juízes ordinários, o que também os índios recusaram. Os vereadores diziam que os índios se consideravam como exclusivos e senhores da vila, que não respeitavam as autoridades e não atendiam nem ao diretor e nem ao vigário. Outra informação interessante indicada pelos vereadores, é que os índios não respeitavam estas autoridades, porque consideravam que elas davam

\footnotetext{
2 Nesta perspectiva, entre tantos trabalhos, veja MONTEIRO, John Manoel. Tupis, Tapuias e Historiadores: Estudos de História Indígena e do Indigenismo. Campinas: Departamento de Antropologia/ IFCH-Unicamp 2001.

${ }^{3}$ Os kiriri-sapuiá era o grupo étnico mais predominante em Pedra Branca e fazia parte do grupo macro-jê. Veja PARAISO, Maria Hilda Baqueiro. De como se Obter Mão-de-obra Indígena na Bahia entre os Séculos XVI e XVIII. Revista de História, São Paulo, 1994.
} 
conselhos opostos a seus interesses (CÂMARA MUNICIPAL DE PEDRA BRANCA, 28 de ago. 1828. APEB, Seção Colonial/Provincial, Maço 1376).

Até então, segundo os vestígios do Diretório dos índios de Pombal (1750), permitiase, nas vilas de índios, a participação dos indígenas no corpo da administração local. Mas a partir de 1828 foram colocadas barreiras normativas a tal participação, como é verificável a partir da Lei de $1^{\circ}$ de outubro de 1828 , sobre a organização administrativa municipal, da Lei de 27 de outubro de 1831, que classificou os índios como incapazes de administrar a si e aos seus bens, colocando-os sob a tutela dos juízes de órfãos e de paz, e da Lei Eleitoral número 387, de 19 de agosto de 1846, que regulou as eleições e proibiu explicitamente à participação dos índios, tanto no sufrágio, quanto na assunção de cargos públicos. A renda e a idoneidade moral, portanto, segundo este arcabouço jurídico, constituíram os maiores obstáculos para o voto ou a eleição de indígenas (REGO, 2009, p. 50-57). Mas até 1835, quando a municipalidade de Pedra Branca será suprimida, os índios, por serem a maioria na vila e por se considerarem donos da vila, lutarão pela participação nos cargos públicos.

Em 1829, a Presidência provincial recorreu ao vigário Manoel de Souza Santos para providenciar a organização da Câmara Municipal eletiva e do juiz de paz. O vigário sublinhou nessa ocasião os obstáculos presentes a tal organização, observando que entre os índios, de quem dependia unicamente a vila, não havia um que tivesse o rendimento de 50 réis, mas que existiam brasileiros com os requisitos para tais empregos, e que os índios não consentiam que pessoas diferentes deles tivessem parte na governança (SANTOS, 20 de jan. 1829. APEB, Seção Colonial/Provincial, Maço 5213). Segundo o escrivão-diretor dos índios, Luiz José de Oliveira, em 1830, a população da vila era constituída por 230 famílias, cerca de 550 indivíduos, sendo os índios a maior parte. O patrimônio dos índios, isto é, as terras, era uma légua em quadro (OLIVEIRA, 9 de jul. 1830. APEB, Seção Colonial/Provincial, Maço 1376).

Em 1833, a Câmara Municipal teve dificuldade na nomeação de juízes e guardas nacionais e a explicação era, outra vez, a oposição dos índios, que estavam na posse de juízes ordinários e não consentiam que pessoas não indígenas fossem admitidas aos empregos. Os vereadores insistiam novamente sobre a não aptidão dos índios para os cargos e sua ignorância e falta de costumes, o que, consequentemente, causava o atraso da vila fundada a mais de 60 anos, não obstante as qualidades do local. Os vereadores questionavam a utilidade da municipalidade, bem como apontavam para uma questão 
crucial, a saber, o rendimento das terras aforadas (CÂMARA MUNICIPAL DE PEDRA BRANCA, 8 de ago. 1833. APEB, Seção Colonial/Provincial, Maço 1376). Era práxis consolidada, desde o período colonial, aforrar lotes de terras dos aldeamentos a particulares, cujas rendas recolhidas destes aforamentos deveriam ser aplicadas às necessidades dos aldeados. Mas geralmente os rendeiros ou não pagavam o combinado ou pagavam o mínimo possível, e este mínimo recolhido ainda podia ser usurpado pelos diretores dos índios ou desviado de sua finalidade pela câmara municipal.

Em março de 1834, por ordem da Presidência provincial, iniciou-se as eleições na vila de Pedra Branca. Um grupo de índios tentou impedir a vereação e, não conseguindo, por temerem o número dos "ditos" cidadãos, se retiraram para as matas, reunindo-se e aliando-se com outras pessoas, pessoas essas que os vereadores denominavam de criminosas. Segundo os vereadores, os revoltosos estavam praticando toda espécie de crimes, roubando os mantimentos e gado, e estavam prestes a entrar na vila, o que seria fácil por não ter força suficiente para a defender. Por isso, foram solicitadas providências de tropa e armamento tanto ao juiz de direito da comarca, como ao Presidente da província (CÂMARA MUNICIPAL DE PEDRA BRANCA, 3 de abr. 1834. APEB, Seção Colonial/Provincial, Maço 1376).

A revolta dos índios era contra a formação do novo corpo legislativo da vila, porque no dizer do juiz municipal, Francisco de Oliveira Guedes, os revoltosos não queriam “outra justiça se não administrada por eles", e estando eles "há mais de trinta anos sem autoridades a quem respeitassem se tornaram bravios, e perigosos" (GUEDES, 21 de abr. 1834; 12 de abr. 1834. APEB, Seção Colonial/Provincial, Maço 2614). Como não conseguiram evitar as eleições e os eleitos não representavam seus interesses, muitos índios se retiraram da vila e se amotinaram nas matas circunvizinhas. Dos fatos narrados em seguida, percebe-se que os revoltosos logo tomaram o controle da vila de Pedra Branca. Dava-se início uma revolta que daria muito trabalho às autoridades locais. $\mathrm{O}$ governo provincial logo recomendou que as autoridades locais chamassem à obediência o grupo sublevado. José Henrique dos Santos, juiz de paz, logo fez uma proclamação de paz, mas somente alguns indígenas apareceram e, por isso, o juiz comunicou sobre a necessidade de estabelecer, na vila, um destacamento de soldados (SANTOS, 23 abr. 1834. APEB, Seção Colonial/Provincial, Maço 2530).

Segundo o major José Antônio, os amotinados eram mais de 300 homens armados, dos quais muitos não eram índios (CASTRO, 20 de mai. 1834. APEB, Seção Colonial/Provincial, Maço 2861). Sob comando do major José Antônio da Silva Castro, 
um destacamento de 130 praças da Guarda Nacional marchou da vila de São Félix para a vila de Pedra Branca. Mas antes de lá chegar, por estratégia, a tropa foi dividida em duas partes e marchou por dois pontos diferentes: um contingente de 70 homens, comandado pelo major José Antônio, entraria pelo sentido vila de Tapera-Pedra Branca, e outro grupo comandado pelo juiz de paz de Tapera, José Egídio da Rocha, entraria pelo local denominado Canabrava (hoje distrito do Município de Elísio Medrado). Os dois grupos deveriam realizar o ataque concomitantemente, ao meio dia de 28 de maio de 1834 (CASTRO, 28 mai. 1834. APEB, Seção Colonial/Provincial, Maço 4611). Mas antes de chegar a Pedra Branca, o major José Antônio enviou aos revoltosos uma proclamação de paz, solicitando-lhes que depusessem as armas, prometendo-lhes todos os meios de segurança e proteção (CASTRO, 28 de mai. 1834. APEB, Seção Colonial/Provincial, Maço 4611). Os índios responderam ao major que estavam prontos a observar as leis, mas que achavam desnecessário que o major viesse "com tanta gente pois por quem vem fazer a paz não é necessário tanto povo. Vossa Excelência pode vir com pouca gente”. E diziam: "só não queremos é o Senhor Guedes que a título de policiar-nos nos quer tirar o direito de propriedade que nós temos por herança de nossos Antepassados" (ÍNDIOS DA VILA DE PEDRA BRANCA, 27 de mai. 1834. APEB, Seção Colonial/Provincial, Maço 4611). Eis aqui a versão dos índios acerca do porquê da revolta. Não era uma mera questão de luta pelo poder em si. Para os indígenas, participar do corpo administrativo da vila significava ter o controle sobre a administração e posse das terras. Para os índios, as autoridades locais, vereadores e juízes, não só não representavam seus interesses como também lhes queriam usurpar o direito de propriedade.

A tropa comandada por Egídio da Rocha, antes de tomar posição no lugar combinado com o major, foi atacada pelos revoltosos, que avantajados pelas emboscadas, depois de duas horas de vivo fogo, forçaram o juiz com a Guarda Nacional a se retirarem, com 6 feridos, 3 gravemente (MEDRADO, 28 de mai. 1834. APEB, Seção Colonial/Provincial, Maço 4611). Já a tropa comandada pelo major José Antônio conseguiu executar o ataque como planejado e entrou em Pedra Branca debaixo de fogo cerrado. Mas o major, vendo-se isolado, com feridos e com força inferior aos quase 300 indígenas, retirou-se de Pedra Branca e colocou acampamento no povoado do Lajedo (Lajedo Comprido, Município de Elísio Medrado). A expedição militar contra os indígenas foi, na realidade, um fiasco (CASTRO, 28 mai. 1834; 6 de jun. 1834. Seção Colonial/Provincial, Maços 4611, 2861). 
Acampado nas proximidades de Pedra Branca, o major esperava por reforços, pois havia solicitado à Presidência provincial alguma tropa de primeira linha com armas, dois mil cartuchos e dinheiro, cujas providências estas ele julgava serem necessárias para em poucos dias obstar os males (CASTRO, 28 mai. 1834. APEB, Seção Colonial/Provincial, Maço 4611). Enquanto isso, o major José Antônio procurava chamar a atenção da Presidência da província para a gravidade da revolta dos índios e ressaltava a necessidade de medidas eficazes para a extinção do foco anárquico, pois ao contrário, logo se verificariam as mesmas cenas ocorridas com revolta dos Cabanos. ${ }^{4}$ A solução proposta pelo comandante era, pois, que o governo lhe fornecesse força de artilharia para romper as trincheiras e dispersar os índios, ficando então fácil para os juízes de paz capturá-los, auxiliados pela tropa (CASTRO, 13 jun. 1834. APEB, Seção Colonial/Provincial, Maço 2861).

No dia 20 de junho de 1834, o major recebeu o reforço de tropa de linha mandado pelo governo provincial, e no dia seguinte marchou contra os índios. Mais uma vez os índios anteciparam o ataque. Mas o reforço à Guarda Nacional surtiu efeito, pois as praças resistiram por duas horas aos tiros disparados pelos rebeldes e conseguiram entrar na vila de Pedra Branca. Já os índios fugiram para as matas circunvizinhas (SILVA, 22 de jun. 1834. APEB, Seção Colonial/Provincial, Maço 2861). De agora em diante os conflitos passarão a ocorrer nas matas adjacentes à vila.

Os juízes de paz de Tapera, José Egídio da Rocha Medrado, e de Pedra Branca, José Henrique dos Santos, propuseram ao major José Antônio que perseguisse os fugitivos. Segundo as informações obtidas por estes juízes, os índios estavam reunidos nas matas do Ribeirão (atualmente a localidade é um distrito de Amargosa), coadjuvados por réus de todos os crimes (CASTRO, 24 de jun. 1834; MEDRADO, 22 de jun. 1834; SANTOS, 23 de jun. 1834. APEB, Seção Colonial/Provincial, Maço 2861). Para isso, destacou-se uma força formada por setenta baionetas, comandada pelo tenente coronel José Rocha Galvão. No dia 24 de junho, marcharam mata adentro contra os revoltosos. No dia 28 do mesmo mês chegaram no sítio de Manuel Nunes. Aqui, de surpresa, os índios atacaram a Guarda Nacional, que respondeu ao fogo e os índios fugiram. A força perseguiu os índios, no dia 30 de junho os emboscou no lugar denominado Cavaco (hoje distrito de Amargosa), repelindo-os com fogo vivo e tomando à força às trincheiras, armas e algumas

\footnotetext{
${ }^{4}$ A Guerra dos Cabanos ou Cabanada, teve início entre maio e junho de 1832, na região que compreendia o norte de Alagoas e o sul de Pernambuco.
} 
munição dos indígenas, ficando da parte da guarda dois feridos e da parte dos índios indícios de ter sofrido grande baixas. A força continuou a marcha na retaguarda dos índios, que foram encontrados a $3 \mathrm{~km}$ mata adentro, no lugar denominado Serra do Brejão (localizada no Município de Brejões), onde foram rechaçados e forçados a abandonar barcas e parte da bagagem (GALVÃO, 2 de jul. 1834; SILVA, 4 de jul. 1834; SAMPAIO, 30 jul. 1834. APEB, Seção Colonial/Provincial, Maço 2861).

No dia $1^{\circ}$ de julho, o comandante marchou com parte da força para explorar o campo, supondo que os índios tinham debandado, porém se enganou. Eles tinham reunido mais combatentes e tomado posição sobre a serra, da qual, favorecidos por superioridade de numérica, trincheiras de pedras e conhecimento do terreno, fizeram fogo irresistível aos guardas. Com pouca munição e posição desfavorável, a tropa do governo se retirou com doze feridos e três mortos. Sentindo-se rodeado de inimigos, o comandante levantou o acampamento e voltou para a vila de Pedra Branca (GALVÃO, 2 de jul. 1834; SILVA, 4 de jul. 1834. APEB, Seção Colonial/Provincial, Maço 2861). José Rocha Galvão chamava a atenção para a gravidade da situação, dizendo serem os malvados em grande número, bem municiados e coadjuvados por um "partido de descontentes do sistema atual”. Ele dizia que se o governo não tomasse medidas eficazes e prontas, logo se teria uma segunda guerra de cabanos no Ribeirão, e que "com pouca força não se podia bater horda de ferozes canibais, que com pretexto de violação de suas terras cometem toda sorte de atentados" (GALVÃO, 2 de jul. 1834. APEB, Seção Colonial/Provincial, Maço 2861). A Câmara municipal da vila de Pedra Branca também pediu providências ao governo provincial contra os índios rebeldes refugiados no Ribeirão (CÂMARA MUNICIPAL DE PEDRA BRANCA, 22 de jul. 1834. APEB, Seção Colonial/Provincial, Maço 1376).

É importante notar a opinião de José Rocha sobre o conflito. A revolta dos índios em Pedra Branca, como já notamos antes, teve como causa os conflitos locais em torno do que os índios defendiam como sendo seus direitos legítimos, principalmente o de uma légua em quadro de terra. Mas José Rocha tenta ampliar a motivação do conflito, relacionando-o com um descontentamento do "sistema atual" e com a revolta dos cabanos, como já tinha feito o major José Antônio da Silva Castro. Ademais, notamos a linguagem do comandante que procurava desqualificar os revoltosos com o velho clichê de "horda de ferozes canibais".

Como por via da força não se conseguia pacificar os revoltosos, talvez, procurando resolver o conflito de forma a evitar maior derramamento de sangue, o Presidente da 
província nomeou uma Comissão para pacificar os índios revoltosos. No dia 15 de agosto de 1834, a Comissão chegou a Curralinho (atual sede do Município de Castro Alves), e o primeiro procedimento que tomou foi retirar a tropa da vila de Pedra Branca para o Curralinho. No dia 23 do mesmo mês, três índios representantes dos revoltosos se apresentaram à Comissão e prometeram respeito e obediência. No dia 24, no lugar chamado Canabrava (como já dito, hoje distrito do Município de Elísio Medrado) a Comissão se encontrou com uma grande porção dos índios, que renovaram a intenção de obediência e respeito. Depois a Comissão se dirigiu para a vila de Pedra Branca para dar providências convenientes ao bem-estar dos índios. Manoel Vieira Costa, juiz de direito da comarca de Cachoeira, encarregado da Comissão, escrevendo ao Presidente da província informou que estava encontrando muitas dificuldades na realização de sua missão e deixava claro que não encontrou nenhuma resistência por parte dos índios (COSTA, 26 de ago. 1834. APEB, Seção Colonial/Provincial, Maço 4611). Embora Manoel Vieira não cite os nomes dos opositores à sua missão, pode-se conjecturar que tal oposição procedesse dos inimigos dos índios, isto é, dos moradores não índios: rendeiros, juízes, autoridades públicas e militares que tinham suas fazendas nos terrenos dos índios e em seus entornos. Fica patente o motivo do conflito: o controle e a posse das terras indígenas.

Não obstante a pacificação dos índios realizada pela Comissão, o problema do município de Pedra Branca restava, ou seja, a falta do tão desejado progresso, cuja falta era atribuída aos índios. O remédio para obstar os males foi, portanto, extingui-lo, mudando a sede do município para o arraial de Curralinho (atual sede do Município de Castro Alves) e anexando seu território ao município de Cachoeira. As razões para esse plano foram motivadas pelo juiz municipal de Pedra Branca, Antônio Caetano de Andrade, que dizia que, depois de mais de 60 anos de existência, a vila nada teve de aumento, senão o de ser elevada de aldeia de índios a vila, e que do estado atual nem o nome de arraial merecia. Para Antônio Caetano de Andrade, Pedra Branca não tinha as condições para ser município pelos seguintes motivos: a existência na vila de uma só casa da Câmara em estado de ruína e poucas palhoças de índios; a insuficiência de terrenos; isolamento das comunicações; falta de comercio; a falta de civilização dos índios; e a falta de homens para os cargos do munícipio (ANDRADE, 5 de mar. 1835. APEB, Seção Legislativa, Série Ofícios Recebidos e Expedidos, Maço 1130).

Já as consequências negativas da mudança do município foram advertidas pelo juiz de paz, Pedro Tales Barreto, que observou que de fato Curralinho oferecia melhores 
comodidades para a sede do município, mas que, com a mudança, os índios, que já se achavam pacificados, ficariam perpetrados nos seus abusos e jamais poderiam civilizarem-se e perder todos os rancores e mau procedimento, pela falta de comunicação e de autoridades que os levassem a boa ordem (BARRETO, 16 de fev. 1835. APEB, Seção Colonial/Provincial, Maço 2530). Mas a Assembleia Legislativa Provincial decretou a extinção do município de Pedra Branca, em 25 de abril de 1835, e anexou seu território ao termo de Cachoeira. O mesmo decreto determinava que o governo provincial fizesse um regulamento adequado, a fim de normatizar regular a administração dos bens dos índios (SÉRIE REGISTROS DE LEIS. APEB, Seção Legislativa, Livro 1, p. 1r-2r, Bahia, 25 de abr. 1835; Atas das Sessões, Sessão de 22 de abr. 1835, Livro 206, p. 120v-121r). Portanto, de município, Pedra Branca voltava à categoria de aldeamento de índios por falta de progresso e de civilização.

\section{Aldeamento de Pedra Branca: medidas das autoridades para controlar os índios e resistência dos índios para se manterem na posse da terra}

Mais de um ano depois da extinção do município, o Presidente da província promulgou, em 20 de junho de 1836, o Regulamento para a administração dos bens dos índios da Pedra Branca. O Regulamento confiou a administração dos bens dos índios a um diretor nomeado pelo mesmo governo. Umas das primeiras tarefas de que deveria se ocupar o diretor, logo que entrasse em exercício, era examinar a porção de terra que constituía o patrimônio dos índios e os títulos pelos quais era possuída, verificando se estavam ou não registradas. Se as terras não estivessem demarcadas, deveria requerê-las, e, se já as fossem, deveria examiná-las e reavivar os marcos (REGULAMENTO PARA A ADMINISTRAÇÃO DOS BENS DOS ÍNDIOS DA PEDRA BRANCA, Bahia, 20 de jun. 1836. APEB, Seção Colonial/Provincial, Maço 4611).

O diretor deveria designar para cada índio casado ou maior de 21 anos uma porção de terra para agricultura, cuja porção deveria ser demarcada e registrada, e cujo dono seria isento de pagar renda. Se algum índio vendesse as benfeitorias a não índio, o comprador deveria pagar arrendamento ao diretor pelas terras ocupadas, exceto se um dos cônjuges fosse índio. Se fosse conveniente e de acordo com o juiz de órfão, o diretor também poderia arrendar alguma porção de terra do patrimônio dos índios a particulares e aplicar as rendas em benefício comum. Ademais, entre as obrigações do diretor, estava a de ensinar - na falta de um professor - a ler e escrever aos índios, 145outrina-los nos 
princípios da religião católica e aconselhá-los e dirigi-los em todos os contratos que eles tivessem que celebrar, a fim de não serem lesados e não desrespeitarem os acordos pactuados (REGULAMENTO PARA A ADMINISTRAÇÃO DOS BENS DOS ÍNDIOS DA PEDRA BRANCA, Bahia, 20 de jun. 1836. APEB, Seção Colonial/Provincial, Maço 4611). O Regulamento é composto de 15 artigos e é interessante notar que quase todos versam sobre o nó da questão e o estopim dos conflitos: as terras dos índios. É interessante notar também o tom paternalista das disposições, considerando os índios como incapazes de administrar seus bens e suas vidas. Ademais, o regulamento não trouxe novidade em matéria indígena, mas constitui-se de práticas do passado, algumas que perpetuavam usos que só causavam conflitos, como por exemplo, a de arrendar lotes de terras do aldeamento a particulares.

Entre 1838 e outubro de 1842, a documentação atesta José Simões de Brito no exercício da diretoria dos índios. A partir de março de 1841, segundo Manoel Joaquim de Sá, a situação na freguesia de Pedra Branca não era das melhores. Ele informava que o diretor estava ausente desde outubro do ano passado e que a situação era perigosa por acharem-se desprovidos de meios para dar providências ao que chamou de "quadrilha de ladrões, matadores e rebeldes" que "viviam só de matar e roubar". Ele ainda acusava o diretor de não ser enérgico e de apoiar os malvados (ALMEIDA, jul. 1838. APEB, Seção Colonial/Provincial, Maço 4613; CÂMARA MUNICIPAL DE CACHOEIRA, 25 de jan. 1841. APEB, Seção Colonial/Provincial, Maço 1270; ANDRADE, 5 de mar. 1841; 6 de mar. 1841. APEB, Seção Colonial/Provincial, Maço 2530). As desordens de vez em quando explodiam na freguesia. Em julho de 1844, 60 índios do Ribeirão entraram na aldeia de Pedra Branca para assassinar o subdelegado, por ter este feito prisioneiros dois índios daquele lugar. Os índios obtiveram a soltura dos presos ([s.a.], 20 de jul. 1844. APEB, Seção Colonial/Provincial, Maço 4611).

A partir de 1845, a diretoria dos índios passou ao tenente coronel Antônio Dias de Oliveira Andrade. No início de 1846, ele solicitou ao governo provincial os meios necessários para o exercício do seu cargo, inclusive o pagamento do ordenado dos guardas que faziam a segurança do lugar, sem os quais ele dizia não poder garantir a paz e a ordem (ANDRADE, 7 de jan. 1846. APEB, Seção Colonial/Provincial, Maço 4611). Mas a paz da qual se sentia orgulhoso o coronel e diretor Antônio Dias não durou muito. Em fevereiro de 1846, ele comunicou à Presidência provincial que não só ele, mas também o pároco, tinham se retirado de Pedra Branca. O motivo da retirada era os desacordos entre o diretor, o juiz de paz e o subdelegado. O diretor falava de ilícitos interesses dessas 
autoridades (ANDRADE, 3 de fev. 1846. APEB, Seção Colonial/Provincial, Maço 4611). A desavença era entre "peixes grandes", mas não deixava de criar divisão entre os índios que escolhiam de que lado ficar.

Em abril de 1846, tomou posse na Diretoria Frutuoso José de Oliveira, que logo procurou comunicar-se com índios sublevados em Ribeirão, que responderam pedindo paz. O diretor exigiu que eles comparecessem desarmados para serem perdoados, ao que obedeceram. Os promotores da desordem eram os índios João Francisco Feliz Baitinga, Joaquim Valente e Joaquim de Santa Ana, os quais, na opinião do diretor, não deveriam ser presos e nem responsabilizados perante a autoridade policial (OLIVEIRA, 20 mai. 1846. APEB, Seção Colonial/Provincial, Maço 4611; OLIVEIRA, 3 de set. 1846. APEB, Seção Colonial/Provincial, Maço 4613). Mas a diretoria de Frutuoso durou pouco. Já em fevereiro de 1847, Manoel Ignácio de Lima, diretor geral dos índios ${ }^{5}$ entre 1846 e 1849 , propôs ao Presidente da província o capitão Luiz Carlos da Silveira para substituir. As acusações contra aquele diretor foram feitas pelo subdelegado da freguesia de São Miguel, Joaquim José Sampaio, e pelos próprios índios que o denunciaram de hostilizar fortemente com os índios que que tinham fugido para as matas de Ribeirão, e isso com a conivência do Juiz de Paz de Pedra Branca (LIMA, 2 de jan. 1847; 4 de jan. 1847. APEB, Seção Colonial/Provincial, Maço 4611; SAMPAIO, 1 de jan. 1847. APEB, Seção Colonial/Provincial, Maço 4611).

Os índios, na sua representação, se diziam desesperados, foragidos e perseguidos pelo diretor Frutuoso e pediam claramente que ele fosse demitido e se nomeasse outro. Diziam ser o diretor um maníaco que só cuidava de fazer imposições odiosas e exigir exorbitantes rendas em proveito próprio e a plantar a desordem e desarmonia entre os índios (ÍNDIOS HABITANTES NA PEDRA, [s.d.]. APEB, Seção Colonial/Provincial, Maço 4611). Da afirmação sobre a cobrança exorbitante de rendas, pode-se conjecturar que a revolta dos índios era também apoiada por alguns proprietários ou rendeiros, pois os índios não pagavam taxas pelas terras que usavam, ou a representação enviada ao governo era feita pelos rendeiros em nome dos índios. De qualquer maneira, exercer o cargo de diretor em Pedra Branca era uma tarefa melindrosa e complicada, cujo executante era chamado a harmonizar seus próprios interesses com os dos índios e dos proprietários locais, o que quase sempre não era possível.

\footnotetext{
${ }^{5}$ A Diretoria Geral dos Índios, foi instituída pela lei n. 426, de 24 de julho de 1845. Este Regulamento acerca das Missões estabelecia um Diretor Geral de Índio para cada Província, nomeado pelo Presidente da província, e um diretor local para cada aldeamento.
} 
Segundo Antônio Péricles, juiz de paz, o chefe Baitinga e seus seguidores andavam com "armas nas mãos" cometendo crimes com o apoio de Joaquim José Sampaio, subdelegado de São Miguel, e do juiz municipal de Nazaré, colocando em total descrédito as autoridades. Para Péricles, o único remédio para os males da Pedra Branca era:

\begin{abstract}
Aldear estes Índios [que fugiram da Pedra Branca e se refugiaram no Ribeirão] em outro lugar longe destes [da Pedra Branca], que de muitos anos existem sempre mais ou menos em lutas com os mais habitantes [...], porque estes Índios que se acham por fora de sua Aldeia, jamais se sujeitarão a nela habitarem, onde se acha um diminuto número deles, porque estes lugares já estão muito habitados, e eles gostam de viverem mais sós (ICÓ, 17 de fev. 1847. APEB, Seção Colonial/Provincial, Maço 2614).
\end{abstract}

Em fevereiro de 1847, tomou posse da diretoria dos índios Luiz Carlos da Silva. Em 28 de março do mesmo ano, ele já comunicava que os índios estavam pacificados e que bastou, para isso, a sua presença e a do vigário que com meios brandos conseguiram que eles depusessem as armas. A dissenção entre os índios tinha como motivo, segundo o diretor, o fato de estar José Henrique dos Santos no exercício de subdelegado, que processava sem ter prestado juramento e era residente na freguesia de Tapera. Para impor o respeito na freguesia, o diretor achava necessário estacionar em Pedra Branca um destacamento (LIMA, 28 de mar. 1847. APEB, Seção Colonial/Provincial, Maço 4611; SILVA, 24 de mai. 1847. APEB, Seção Colonial/Provincial, Maço 4611).

Já para os moradores de Tapera, os agravos praticados pelos índios de Pedra Branca, que viviam nas matas do Ribeirão, eram frutos dos jogos de interesses das autoridades locais. Eles afirmavam que os índios há alguns anos estavam sem governo, isso porque os diretores e algumas autoridades só tinham servido para dividi-los em partidos para desfrutá-los e viverem de suas depredações, desordens que consequentemente faziam com que os índios deixassem de entregar-se ao trabalho honesto, vivendo em bandos e exercendo a rapina, que além de "ser uma corporação unida, era tida e mantida sob a sombra da inocência pelas autoridades principais" (ABAIXO-ASSINADO DOS MORADORES DA TAPERA, 3 de mar. 1847. APEB, Seção Colonial/Provincial, Maço 4611). O diretor, Luiz Carlos, respondeu aos protestos dos moradores de Tapera dizendo que os índios que estavam no Ribeirão tinham voltando a se estabelecer pacificamente em Pedra Branca, inclusive o chefe Baitinga (SILVEIRA, 18 de jul. 1847. APEB, Seção Colonial/Provincial, Maço 4611).

Da diretoria do aldeamento aos missionários capuchinhos: "os melhores diretores de índios" 
Em junho de 1847, os índios pediram ao diretor que o missionário capuchinho frei Agostinho de Casarano permanecesse em Pedra Branca. Provavelmente o religioso estava de passagem por aqueles lugares. Diante das autoridades competentes, o diretor justificou a permanência do religioso dizendo que ele com as "palavras da Religião" podiam "harmonizar os Índios, e fazer acalmar-lhes as paixões, e dissensões em que ardiam" (SILVEIRA, 8 de jun. 1847. APEB, Seção Colonial/Provincial, Maço 4611). O diretor geral dos índios achou razoável o que eles pediam e solicitou ao Presidente da província que o pedido fosse deferido. (LIMA, 2 de jul. 1847. APEB, Seção Colonial/Provincial, Maço 4611). No dia 17 de agosto, frei Agostinho fixou-se na aldeia de Pedra Branca, decisão esta que deixou os índios e os moradores muito satisfeitos, segundo o diretor Luiz Carlos (SILVEIRA, 24 de ago. 1847; LIMA, 3 de set. 1847; SILVEIRA, 6 de out. 1847; LIMA, 13 de out. 1847; 21 de nov. 1847. APEB, Seção Colonial/ Provincial, Maço 4611).

No início de janeiro de 1848, ocorreu outro tumulto na aldeia de Pedra Branca. Dezesseis indivíduos armados, que frei Agostinho dizia serem mais rendeiros do que índios, insultaram o diretor e subdelegado Luiz Carlos da Silveira. Segundo Silveira, eles haviam sido insuflados por frei Jacinto de Santa Clara, carmelita e vigário encomendado da freguesia que, com pretexto de descontentamento eleitoral, queria que o diretor renunciasse a seu posto. Segundo o diretor geral dos índios, o frei Jacinto procurava afastar o atual diretor para que seu irmão fosse nomeado em seu lugar na respectiva aldeia. Romualdo Antônio de Seixas, arcebispo da Bahia, entre 1827 e 1860, ordenou que o vigário frei Jacinto se recolhesse no seu convento e autorizou frei Agostinho a exercer as funções paroquiais. Devido às condições do local e as dificuldades para encontrar pároco que quisesse administrar a freguesia, o arcebispo já havia até proposto ao governo provincial a extinção da freguesia (SILVEIRA, 7 de jan. 1848; CASSARANO, 7 de jan. 1848; LIMA, 12 jan. 1848. APEB, Seção Colonial/Provincial, Maço 4611; SEIXAS, 22 de jan. 1848; 23 de jan. 1848. APEB, Seção Colonial/Provincial, Maço 5205; SEIXAS, 22 de abr. 1846. APEB, Seção Legislativa, Série Ofícios Recebidos e Expedidos, Maço 1140).

Como solicitado pelo diretor Luiz Carlos da Silveira, também foi enviada a Pedra Branca uma força militar para prender os criminosos e garantir a tranquilidade e o respeito à lei, mas chegando à Cachoeira, a força não prosseguiu. Segundo o comandante da força, em Pedra Branca não havia recursos de víveres para manter a tropa e a força era diminuta 
no confronto dos malvados (SILVEIRA, 26 de fev. 1848. APEB, Seção Colonial/Provincial, Maço 4611; LIMA, 27 de fev. 1848. APEB, Seção Colonial/ Provincial, Maço 4611; MIRANDA, 12 de set. 1848. APEB, Seção Colonial/Provincial, Maço 4611). Em abril de 1849, foi nomeado para diretor dos índios da Pedra Branca Antônio Esteves Paraens, por ter pedido demissão do cargo Luiz Carlos da Silveira. Porém, Já em março de 1850, o diretor geral dos índios pediu ao Presidente da província que Antônio Esteves fosse demitido do emprego e fosse nomeado como diretor o missionário atual da aldeia, frei Agostinho de Casarano, dizendo que a experiência tinha mostrado que os missionários capuchinhos eram os melhores diretores de índios e que só desse modo poderia-se conservar a tranquilidade e extinguir as intrigas (LIMA, 18 de jan. 1849; 28 de abr. 1849. APEB, Seção Colonial/Provincial, Maço 4611; MADUREIRA, 21 de mar. 1850. APEB, Seção Colonial/Provincial, Série Maço 4611).

Até então frei Agostinho estava como vigário encomendado dos índios, ou seja, responsável somente pela administração espiritual; a partir de 1850, com sua nomeação a diretor dos índios, ele passava também a administrar o aldeamento no âmbito temporal. Mas nesse mesmo ano ele deixou a direção da aldeia. Os documentos não nos permitem saber o motivo do afastamento do religioso, mas o certo é que, em julho do mesmo ano, frei Serafim de Petralia, ${ }^{6}$ missionário capuchinho, já se encontrava como seu substituto e escrevia a Casimiro de Sena Madureira, diretor geral dos índios entre 1850 e 1858, dizendo que era impossível continuar em Pedra Branca com um ordenado de 300 mil réis anuais e que ou se subministrava os meios indispensáveis para o desempenho do seu cargo ou seria melhor ser demitido. Casimiro pediu ao governo que abonasse ao religioso uma gratificação que fosse condizente com as condições do lugar. Frei Serafim também pediu autorização para formar uma pequena força militar composta de índios, que deveriam ser assalariados e cuidar da segurança individual e pública, ficando sob sua direção. A ideia também pareceu razoável ao diretor geral dos índios, mas o governo provincial não autorizou a criação da força, alegando a falta de meios econômicos para isso e observando que a falta da força fosse suprida pelo dobro do zelo do missionário, que no caso de necessidade deveria dirigir-se às autoridades para ser auxiliado convenientemente (PETRALIA, 7 de jul. 1850; MADUREIRA, 18 de jul. 1850. APEB, Seção Colonial/Provincial, Maço 4611).

\footnotetext{
${ }^{6}$ Frei Serafim de Petralia, missionário Capuchinho, da província de Messina, Itália chegou ao Brasil em 1843 e voltou para Itália em 1870. Cfr. AHNSP, Caixa B-8, Libro Mastro, p. 42.
} 
Segundo o relatório do diretor geral dos índios de 1851, a população indígena em Pedra Branca era cerca 380 indivíduos. Outros índios dessa aldeia haviam se transferido para Ribeirão, e outros para as margens do rio de Contas no distrito de Jequiriça. Já em 1852, os índios eram 287. Segundo o diretor geral dos índios, a explicação para a diminuição da população entre 1851 e 1852 era a migração para os lugares acima mencionados, por indígenas que continuavam abandonando a aldeia para viverem sem sujeição ao missionário-diretor. Havia nas terras da aldeia 300 indivíduos não índios ou rendeiros, que pagavam as taxas pelas terras arrendadas, das quais foi recolhida, em 1850, a quantia de 237 mil réis, dinheiro que, segundo o diretor geral, foi aplicado por frei Serafim no conserto da igreja e numa prensa de fazer farinha de mandioca. Havia na aldeia um professor de primeiras letras pago pelo cofre provincial (MADUREIRA, 1851, p. 3; MADUREIRA, 1852, p. 3). Questionada a Câmara da vila de Tapera pelo governo provincial sobre o estado dos índios e da aldeia de Pedra Branca e das medidas tomadas para melhorar esse serviço, em fevereiro de 1851, ela respondeu que quanto ao estado de civilização

hoje estão [os índios] tão cruzados que apenas se contará trinta famílias de
verdadeiros índios na cor, computando-se todos os aldeados em seis centos
almas, sendo a maior parte deles cruzados com negros; têm eles todos os usos
e hábitos dos mais habitantes Nacionais, se bem que conta que uma pequena
fração deles ainda pratica gentilicamente cerimônias religiosas, depois que
acabam de receber as da verdadeira Religião (RELATÓRIO DA CÂMARA
DA VILA DE CONCEIÇÂA DA TAPERA, 15 de fev. 1851. AHNSP, Caixa
Ea 4, Missões).

Quanto à légua em quadro de terra, a Câmara Municipal informou que estava sem medir, o que tinham sempre suscitado questões com os terrenos confinantes, que queriam sempre mais do que lhes pertenciam, a tal ponto que estavam povoando as vizinhanças da aldeia, o que causava a fuga dos índios mais indomáveis que vagavam de lugar em lugar, estabelecendo-se nas matas, em domínios particulares, sem consentimento, e onde abundava a caça. Quanto à indústria, os vereadores sublinhavam que nem mesmo a da construção das casas os índios exercitavam, contentando-se com simples ranchos de palha. Quanto à lavoura, informava que eles cultivavam pequenas plantações de milho, feijão e mandioca. A “desmoralização" entre os índios tinha chegado a tal ponto que os vereadores diziam ser indispensável para eles a catequese, sendo os mestiços de cor preta os mais viciosos que os bravos. A causa de tudo isso, segundo os vereadores, primeiramente teria sido dos antigos habitantes das vizinhanças, com exceção de alguns, e dos diretores que, tirados das classes menos moralizadas, não se importaram de corrigir 
os maus hábitos dos índios, antes alimentando as divisões com as falsas ideias de fazeremse amigos dos índios (RELATÓRIO DA CÂMARA DA VILA DE CONCEIÇÃO DA TAPERA, 15 de fev. 1851. AHNSP, Caixa Ea 4, Missões).

Para melhorar a situação dos vereadores de Tapera diziam ser necessário chamar os errantes ao grêmio de sua aldeia e para isso precisava-se, primeiro, nomear um diretor capuchinho, como já havia sido feito, mas, segundo os vereadores, embora ele tivesse a força moral, pouco podia fazer por lhe faltar a força física para melhor ser respeitado; segundo, medir as terras da aldeia dividindo-as e impondo penas corporais ou perda do direito àqueles que se estabelecessem fora dela, salvo pelo domínio ou compra legal; terceiro, remover os chefes para aldeias longínquas, ou criar uma nova aldeia nas matas do rio das Contas com cinquenta famílias e um diretor religioso, a qual seria procurada por outros após a fundação, podendo-se no futuro eliminar a aldeia de Pedra Branca, vendendo as terras conforme a lei. Era necessário também, segundo os vereadores, um professor, que já havia em Pedra Branca, mas que para que fosse frequentada a escola, era necessário que à custa dos rendimentos das terras, fossem vestidos os meninos que a frequentassem, ao contrário, as crianças não a frequentariam por causa da pobreza extrema dos índios (RELATÓRIO DA CÂMARA DA VILA DE CONCEIÇÃO DA TAPERA, 15 de fev. 1851. AHNSP, Caixa Ea 4, Missões).

As matas eram o refúgio dos índios não só para escapar das perseguições, mas também das doenças. Em março de 1851, frei Serafim informava que a "peste das bexigas" ou varíola, que há mais de um mês se propagava na freguesia, tinha amedrontado os índios, a maioria dos quais tinha se retirado para as matas. Para evitar essa fuga e fazer regressarem os fugitivos, ele pedia que lhe enviassem vacina e determinassem uma pessoa para administrá-las, indicando para essa tarefa o professor João da Silva Márquez. Em 1855, o delegado de Tapera falava da contínua mortandade de índios nas matas (PETRALIA, 23 de mar. 1851; MADUREIRA, 31 de mar. 1851; FALERNA, 26 de dez. 1853. APEB, Seção Colonial/Provincial, Maço 4611; MAPA DAS ALDEIAS DA PROVÍNCIA DA BAHIA, 9 de fev. 1855. APEB, Seção Colonial/Provincial, Maço 4613; SILVA, 8 de out. 1855. APEB, Seção Colonial/Provincial, Maço 2992). O abandono, portanto, da aldeia pelos índios, entre 1851 e 1855, se deu também por causa da epidemia da varíola.

Depois de mais de um ano na direção dos índios, frei Serafim se retirava, dizendo terem sido seus “apostólicos trabalhos" improfícuos. Ele dizia que os índios, em vez de se mostrarem gratos aos benefícios, se tornavam cada vez mais atrevidos, "levantando a 
cabeça contra seus benfeitores e insultando todas as autoridades" (PETRALIA, 24 de mai. 1851. APEB, Seção Colonial/Provincial, Maço 5308). O missionário apontava o nome dos índios João Felix Baitinga, Manoel Honório, Antônio Cabral e Narciso, como sendo os mais célebres insubordinados, e sendo o furto, o despotismo, os homicídios e o ócio a causa original da imoralidade dos índios. A decepção do missionário era evidente e atribuía a falência da sua missão somente aos índios. Ele era talvez incapaz de compreender aquela complexa realidade, o porquê do comportamento dos índios que fora condicionado pelas históricas relações de interesses, exploração e conflitos.

Ajuda-nos compreender melhor a questão João Ferreira Luiz, delegado interino, que questionado a respeito do protesto dos índios ao Conselho de Qualificação, respondeu que era sabido por todos que os índios de Pedra Branca não se uniam com os habitantes da vila de Tapera, nos quais reconheciam seus maiores flageladores, principalmente a família Guedes. Não obstante reconhecesse que alguns índios fizessem roubo de gado, João Ferreira dizia que a verdade incontestável era que os índios sofriam, eram perseguidos e mortos. Ele não tinha dúvida de que eram os 300 rendeiros e os moradores circunvizinhos de Pedra Branca eram os instigadores das desavenças entre os índios, e que o atual motivo da oposição deles era os mesquinhos interesses ou vinganças particulares de um parente do tenente coronel Guedes, de nome Nunes de Queiroz. Para o delegado, a anexação do território de Pedra Branca à vila de Tapera tinha sido uma decisão imprudente. As providências indicadas por ele, eram:

[...] demarcar-se aos Índios os verdadeiros limites da légua de terra da sua Aldeia, e excluir os mencionados rendeiros, pois a eles devem os Índios os males, que sofrem, porque se apresentam facilmente por diante nas coisas, e são sempre as vítimas, além do descrédito de amotinadores, quando realmente sabidos são humildes, e obedientes a quem os guia, reconhecendo o grande poder do Presidente da Província, a quem recorrem logo que se julgam ofendidos em seus direitos (LUIZ, 6 de jun. 1851. APEB, Seção Colonial/Provincial, Maço 5308).

Com a notícia de que frei Serafim se retirava da aldeia até mesmo antes de receber as ordens do Presidente da província, por não poder conter os índios, o diretor geral dos índios foi até ao Convento de Nossa Senhora da Piedade (Salvador) e obteve que frei Agostinho de Casarano retornasse à Pedra Branca. O diretor geral resolveu ainda que o Conselho de Qualificação da Guarda Nacional não fosse instalado em Pedra Branca, onde ele dizia residir somente índios que não eram independentes e não possuíam rendas, ou seja, não tinham os requisitos legais para serem guardas, por estarem ainda precisos de civilização e da direção excepcional do missionário-diretor e ainda recebiam os socorros 
do governo. $\mathrm{O}$ diretor geral acreditava que frei Agostinho com sua energia e prudência pudesse evitar as desordens que tanto temia frei Serafim. Quanto aos índios João Felix Baitinga, Manoel Honório, Antônio Cabral e Narciso, que estavam acoitados nas matas do Ribeirão, seria conveniente encarregar os delegados de Nazaré e de Tapera para prendê-los (MADUREIRA, 6 de jun. 1851. APEB, Seção Colonial/Provincial, Maço 4611).

Segundo Antônio Péricles Souza Icó, juiz municipal e de órfãos, Baitinga chefiava um grupo de cerca de 200 indígenas. O juiz enquadrava a situação com tom muito grave, dizendo que Baitinga há tempo estava se preparando para a guerra e cometendo os mais cruéis assassinatos e roubos naquelas localidades. Para conter as desordens e prender os culpados, o juiz solicitou ao governo provincial o envio de força suficiente (ICÓ, 3 de jan. 1853; 4 de jan. 1853; 8 de jan. 1853. APEB, Seção Colonial/Provincial, Maço 2614; OLIVEIRA, 8 de jan. 1853. APEB, Seção Colonial/Provincial, Maço 2614). As autoridades militares de Nazaré, São Miguel e Tapera se mobilizaram para colocar fim nas desordens. Segundo as informações obtidas por estas autoridades, Baitinga estavam "levando a ferro e fogo" os habitantes de Ribeirão (SILVA, 4 de jan. 1853; PARANAGUÁ, 9 de jan. 1853; SILVA, 8 de jan. 1853. APEB, Seção Colonial/Provincial, Maço 2991; BAHIA, 7 de jan. 1853. APEB, Seção Colonial/Provincial, Maço 2505). Manoel Joaquim Bahia, juiz de direito, dizia não saber a causa dos procedimentos criminosos dos índios, mas que era certo que eles costumavam lançar mãos às armas com o pretexto de terem sido espoliadas as terras em que habitavam. Já o delegado Antônio Moniz Barreto da Silva, fazendo referência a uma carta que Baitinga teria escrito ao $1^{\circ}$ suplente da subdelegacia de São Miguel, afirmava que Baitinga aludia ao fato de ter sido agredido, o que segundo o delegado não era verdade, porque os proprietários que eles tinham atacado apenas se conservaram em atitude de defesa. Já João Lustosa Paranaguá, delegado de Tapera, informava que o pretexto da sublevação dos índios tinha sido a perpetração de alguns assassinatos na povoação de Amargosa em que foram vítimas alguns índios por pessoas do lugar (SILVA, 16 de jan. 1853. APEB, Seção Colonial/Provincial, Maço 2991; PARANAGUÁ, 22 de jan. 1853. APEB, Seção Colonial/Provincial, Maço 4611).

A força marchou contra os índios mas eles, prevenidos do ataque, que poderiam sofrer se concentraram e se entrincheiraram nas matas da povoação de Amargosa. Era uma estratégia dos índios mudar de termo, para dificultar o trabalho das autoridades que não podiam prendê-los em lugar onde a força não tinha jurisdição. Portanto, o juiz de 
direito de Nazaré, Manoel Joaquim Bahia, pediu que todas as autoridades dos termos limítrofes colaborassem na prisão dos índios, principalmente dos índios Baitinga e Narciso, que eram os chefes das desordens (BAHIA, 13 de jan. 1853. APEB, Seção Colonial/Provincial, Maço 2505; SILVA, 16 de jan. 1853. APEB, Seção Colonial/Provincial, Maço 2991).

João Lustosa Paranaguá, depois de falar com frei Agostinho, assumiu um tom mais conciliante e recomendou ao comandante da força que os índios que depusessem as armas, deveriam voltar as suas habitações e respectivas aldeias e os culpados presos. De fato, no dia 26 de janeiro, o sobredito delegado comunicou ao Presidente da província que a tranquilidade tinha se restabelecido no termo de Tapera. Com a marcha da força e mediante a dedicação do missionário-diretor frei Agostinho, os amotinados, em número de 200 indivíduos, se mostraram submissos e desejosos de sossego. Desses índios, somente 60 se apresentaram depois ao comandante da força, que "depois de uma prática apropriada do reverendo missionário" (PARANAGUÁ, 26 de jan. 1853. APEB, Seção Colonial/Provincial, Maço 2991) os fez voltar as suas habitações. Mas muitos dos índios não se apresentaram e continuaram dispersos.

A força permaneceu em Amargosa e Ribeirão. Muitos indígenas estavam espalhados e ocultos em ato de observação, conservando-se no lugar denominado Muriçoca com o chefe Baitinga, distante da força três léguas, por isso o juiz municipal julgou necessário a permanência do destacamento com 30 a 40 soldados naquelas paragens por algum tempo, e 12 na vila de Tapera para garantir as ordens das autoridades e observar os índios de Pedra Branca (ICÓ, 31 de jan. 1853. APEB, Seção Colonial/Provincial, Maço 2614).

O major Guilhermino da força de Amargosa, no dia 13 de março de 1853, preparou uma emboscada aos índios que ainda estavam pelas matas, onde foram presos 33 deles, inclusive os chefes João Baitinga e Narciso. Esse acontecimento foi comunicado ao Presidente da província pelo juiz municipal como sendo uma "feliz notícia" (ICÓ, 14 mar. 1853. APEB, Seção Colonial/Provincial, Maço 2614). Um grupo de índios de Pedra Branca buscou refúgio e se estabeleceu nas margens do rio das Contas (FALERNA, 26 de dez. 1853. APEB, Seção Colonial/Provincial, Maço 4611; MADUREIRA, 3 de out. 1854. APEB, Seção Colonial/Provincial, Maço 4612). Não sabemos qual foi o fim de Baitinga e Narciso. O certo é que depois dessa prisão os nomes deles desapareceram das correspondências das autoridades. 
Em outubro de 1857, foi solicitado ao frei Agostinho que fizesse o registro das terras. A esse pedido o religioso apresentou algumas dúvidas ao delegado da Repartição das Terras: se Pedra Branca, uma aldeia de antiga fundação e criada com Decreto Real de doação de terra estaria no caso de ser incluída no número dos registros. Ele explicava ainda que não era fácil fazer tal registro, porque não existiam os documentos da criação da aldeia - documentos que ele pensava que estivessem no arquivo da Diretoria Geral dos índios - e que somente por tradição dos índios mais velhos sabia que as terras abrangiam uma légua em quadro, confinando ao nascente e ao norte com as terras de Curralinho (atual sede do Município de Castro Alves), ao sul com as terras do arraial de Santa Ana de Jibóia (atual distrito de Monte Cruzeiro), e ao poente com as da vila de Conceição de Tapera (atual Castro Alves). Frei Agostinho observou que existiam vários sítios de rendeiros, não sendo eles terrenos próprios, mas posses de benfeitorias, das quais o frei também duvidava se deveriam ser registradas. Quanto ao documento de criação da aldeia, segundo o que os índios referiram a frei Rainero de Ovada, ele teria desaparecido do arquivo da diretoria da aldeia no tumulto ocorrido em 1834 (CASARANO, 3 de nov. 1857. APEB, Seção Colonial/Provincial, Maço 6508; OVADA, 21 set. 1859. APEB, Seção Colonial/Provincial, Maço 4612).

A resposta do delegado das Terras às dúvidas de frei Agostinho foi que o artigo 91 do Regulamento de 30 de janeiro de 1854 não excluía da obrigação do registro as terras pertencentes aos índios. Já os possuidores de terras não eram obrigados a exibir título ou documentos no ato do registro, devendo ser aceitas as declarações por mais duvidosas que fossem e tanto o sesmeiro como o foreiro deveriam registrar as terras (OVADA, 21 set. 1859. APEB, Seção Colonial/Provincial, Maço 4612; ROCHA, 29 de jan. 1858. APEB, Seção Colonial/Provincial, Maço 7030). Não consta que frei Agostinho tenha realizado o registro das terras, pois morreu em 20 de janeiro de 1858. Ao mesmo tempo em que o juiz municipal e de órfãos, Antônio Péricles Souza Icó, comunicava a morte do missionário, pedia que fossem mandados com urgência outro sacerdote e um diretor, a fim de conter os índios da freguesia. Quanto à nomeação do novo diretor, o juiz Antônio pensava que a escolha de um militar, que também fosse nomeado subdelegado com algumas praças para guarda e segurança, colheria mais frutos, porque poderia conter os furtos dos índios, obrigá-los ao trabalho e ainda prender os criminosos que se acoitavam entre eles. Quanto ao vigário ele afirmava que conviria ser dos capuchinhos, "visto que nenhum dos nossos padres quererá se sujeitar só pela côngrua e talvez (tal seja ele) que concorra para se formarem partidos entre os Índios, o que não será novo ali, de mais a 
mais sempre existiu entre eles rivalidades de nações [...]" (ICÓ, 21 de jan. 1858. APEB, Seção Colonial/Provincial, Maço 2614).

Como não havia missionário capuchinho disponível para o cargo, as autoridades civis de acordo com as autoridades religiosas exoneraram frei Rainero de Ovada de diretor da aldeia de São Pedro de Alcântara e o nomearam vigário e diretor de Pedra Branca, que passou a exercer o cargo a partir de maio de 1858 (MADUREIRA, 18 de mai. 1858. APEB, Seção Colonial/Provincial, Maço 4612; SEIXAS, 20 de mai. 1858. APEB, Seção Colonial/Provincial, Maço 5203). (DORIA, 29 de mar. 1859. APEB, Seção Colonial/Provincial, Maço 4612).

As tensões na aldeia eram uma realidade sempre presente. Em março de 1859, segundo o mesmo juiz municipal e de órfãos, Antônio Péricles, os índios se encontravam na "quase completa desordem, prestes a levantarem uma revolta com o fim talvez de roubarem e de exercitarem vingança", sendo necessário para contê-los uma "força física dirigida por uma autoridade especial" (ICÓ, 11 de mar. 1859. APEB, Seção Colonial/Provincial, Maço 2614) que exercitasse a justiça criminal. Ao missionário e diretor frei Rainero não faltaram momentos de tensões na administração da aldeia, como o ocorrido em meados de junho de 1859, quando o religioso mandou fechar as portas de uma pequena venda e expulsou o proprietário Manoel Ignácio Pereira da aldeia. Manoel, segundo o religioso, era um homem turbulento e de péssimos costumes e foi expulso por causa dos incômodos que causava à diretoria com suas repetidas desordens (OVADA, 20 de ago. 1859. APEB, Seção Colonial/Provincial, Maço 4612).

Em 1860, segundo os dados fornecidos por frei Rainero, os habitantes da freguesia de Pedra Branca eram 775 pessoas. Quanto aos índios, ele dizia que existiam poucas famílias, o que comprova mais uma vez a dispersão dos índios. A economia dos moradores era a plantação em pequena escala de diversos gêneros. Quanto às rendas das terras, pouco se obtinha porque os rendeiros pouco ou nada pagavam (OVADA, 20 de dez. 1860. APEB, Seção Colonial/Provincial, Maço 6509; MAPA DAS ALDEIAS INDÍGENAS DA PROVÍNCIA DA BAHIA, 14 de jan. 1861. APEB, Seção Colonial/Provincial, Maço 4610).

Em 1863, um abaixo-assinado de dez pessoas, que diziam ser os índios de Pedra Branca, pediu ao governo provincial que ordenasse que fossem cobradas as rendas das terras para o benefício da igreja, isso porque frei Rainero nunca tinha se importado em fazer benefício para o bem do povoado, explicavam os abaixo-assinados. Pediam ainda 
que um tal José fosse encarregado da cobrança das rendas e um professor de primeiras letras ([s.a.], 29 de out. 1863. APEB, Seção Colonial/Provincial, Maço 4612). Frei Rainero deixou a direção da aldeia de Pedra Branca no início de 1863. Segundo o superior do religioso, ele deixou a direção da aldeia por motivo de saúde (SILVEIRA, 22 de jan. 1863. APEB, Seção Colonial/Provincial, Maço 5204).

\section{A diretoria do aldeamento depois da saída dos missionários capuchinhos}

Depois da demissão de frei Rainero, não foram mais nomeados missionários capuchinhos para a freguesia. Em abril de 1864, o delegado da Cachoeira, Trasíbulo de Rocha Passos, representou ao governo provincial sobre o péssimo procedimento dos índios, que não se dedicavam ao trabalho e viviam do furto de gado e da lavoura. Trasíbulo dizia que o meio para terminar as desordens era extinguir a aldeia, mas como isso era difícil, pedia ao presidente que ordenasse ao comandante do destacamento de Amargosa que fosse mensalmente naquele distrito e empregasse esforços para capturar os chefes que eram conhecidos. Observou ainda que o subdelegado da freguesia nada fazia porque não queria intrigar-se com os índios (PASSOS, 23 de abr. 1864. APEB, Seção Colonial/Provincial, Maço 2994). Somente em junho de 1866, foi nomeado como capelão dos índios o padre Antônio Ângelo Gomes de Mendonça com a gratificação de 240 mil réis (VERMELHO, 30 de jul. 1866. APEB, Seção Colonial/Provincial, Maço 4614). Já em agosto de 1868, estava como vigário e diretor o padre Manoel Glória Pitta. Ele descreveu o estado da aldeia com traços desoladores: no arraial havia dez casas cobertas de telhas de uma porta e janela; cinco casas cobertas de palhas; a casa do diretor e a igreja estavam bastante deterioradas; a mais pobre população vivia às despesas dos índios, dos quais se utilizavam para plantar fumo a troco de cachaça e compravam seus furtos por bagatelas. O vigário-diretor se dizia sozinho, isolado, doente e sem ninguém que lhe servisse para a correção dos índios e que seus pedidos de ajuda às autoridades policiais tinham ficado sem efeito (PITTA, 9 de ago. 1868. APEB, Seção Colonial/Provincial, Maço 5313). Padre Manoel Glória Pitta se retirou para a freguesia de Tapera, e em fevereiro de 1869 foi nomeado o padre Cirilo Alexandrino de Oliveira (VERMELHO, 27 de fev. 1869; SOUSA, 24 de mar. 1869. APEB, Seção Colonial/Provincial, Maço 4614).

Em maio de 1867, era a vez do juiz municipal e delegado de Tapera comunicar que, depois da saída do destacamento, os índios de Pedra Branca estavam invadindo os sítios 
armados, desobedecendo tanto ao diretor como ao subdelegado. Ele dizia que os índios estavam divididos em duas tribos em desarmonia, os tapuias e os cariris, a cuja desordem era agravada por especuladores. O juiz se dizia sem força para manter a ordem, por ter se retirado o destacamento e por estar a respectiva delegacia sem meios (ALBUQUERQUE, mai. 1867. APEB, Seção Colonial/Provincial, Maço 2614). Já em outubro de 1870, era Francisco da Rocha Medrada, proprietário da fazenda Mangabeira, situada no termo de Tapera, e distante três léguas da aldeia de Pedra Branca, que denunciava os furtos perpetrados há mais de dois anos pelos índios. Francisco acusava tanto o diretor, padre Cirilo, como o delegado de serem coniventes com os atos praticados pelos indígenas e pedia que a delegacia fosse dada ao juiz municipal Fernando e a diretoria dos índios a um padre capuchinho (MEDRADE, 15 de out. 1870. APEB, Seção Colonial/Provincial, Maço 4614). A aldeia, segundo Cirilo, estava em completa anarquia, onde todos mandavam e todos governavam e que há meses reinava a imoralidade e o desrespeito às leis e às autoridades na aldeia e na freguesia, onde "os clavinotes, e punhais cruzam-se ao público sem limites" (SOUZA, 18 de nov. 1870. APEB, Seção Colonial/Provincial, Maço 4614). Os agentes da desordem, segundo Cirilo, não eram somente os índios, mas também os rendeiros, ou melhor, eram principalmente os rendeiros os que procuravam desacreditar o diretor e que introduziam cizânias entre os índios, tudo isso para se beneficiarem da situação de confusão. Cirilo falava de rendas vencidas há dois anos, títulos falsos e terras arrendadas por quantias ridículas. $\mathrm{O}$ padre-diretor reconhecia não ter podido fazer reinar a ordem através de meios brandos. Os índios já não lhe estavam obedecendo e não tinha força para repelir os desordeiros, e por isso solicitava ao governo provincial dez soldados para poder impor a tranquilidade (SOUZA, 18 de nov. 1870. APEB, Seção Colonial/Provincial, Maço 4614).

O delegado Antônio Vieira Sampaio de Tapera, era da opinião que o padre Cirilo não gozava do prestígio indispensável para, por meios brandos, impor o respeito e manter a disciplina entre os indivíduos. Portanto, dizia tinham ser preciso empregar a força física para garantir a ordem. As dificuldades com as quais lidava o diretor Cirilo, segundo Antônio Vieira, tinham como causa a concessão indiscriminada dos arrendamentos, que ao invés de escolherem pessoas moralizadas e dedicadas ao trabalho para ocupar os terrenos, foram arrendados a qualquer pessoa. Portanto, para Antônio Vieira, em vez de mandar 10 soldados para Pedra Branca, era mais acertado declarar extinto o aldeamento, colocando em hasta pública os terrenos e conservando, na posse dos sítios demarcados, 
os índios que existissem. Sugeria Vieira que, com essa medida, o governo provincial lucraria e, ademais, obteria o progresso material da freguesia de Pedra Branca, aonde iriam pessoas trabalhadoras e industriosas, atraídas pela fertilidade dos terrenos. Para esse delegado, em Pedra Branca só existiam descendentes da "raça" dos índios aldeados há muitos anos, que já estavam civilizados, ou seja, vivendo em sociedade, dedicando-se à lavoura, cujos produtos conduziam para Curralinho e Amargosa. O Diretor Geral dos índios, Barão de Sergimirim, na sua representação ao Presidente da província, repetirá e proporá as mesmas soluções indicadas pelo delegado Antônio Vieira (SAMPAIO, 20 de dez. 1870; PINTO, 18 de jan. 1871; SERGIMIRIM, 12 de jan. 1871. APEB, Seção Colonial/Provincial, Maço 4614).

Em março de 1871, o diretor, padre Cirilo, diante da situação acima narrada, e dizendo não ser lícito perder a vida que achava ameaçada, não pelos índios, mas por um grupo de desordeiros embriagados que perturbavam a ordem pública, pediu exoneração do seu cargo. Para substituí-lo foi nomeado frei Teodoro da Divina Providência (SOUZA, 04 de mar. 1871. APEB, Seção Colonial/Provincial, Maço 4614; SERGIMIRIM, 7 de jul. 1871. APEB, Seção Colonial/Provincial, Maço 4614). Tal situação de desordem é confirmada pelo juiz municipal e delegado de Tapera, Joaquim Simões, que definia a aldeia de Pedra Branca como um refúgio de criminosos e vadios, onde reinava as desordens e de onde saíam diversas quadrilhas de ladrões de gado pelas circunvizinhanças (SILVA, 25 de abr. 1871; 5 de mar. 1871; 5 de mar. 1871. APEB, Seção Colonial/Provincial, Maço 2614).

Em novembro de 1873, a diretoria dos índios se achava novamente vacante e foi nomeado Antônio Rodrigues de Aquino Tanajura. Portanto, era nomeado um diretor leigo e a motivação para nomeá-lo não era mais para guiar os índios, mas a fim de que os "emigrantes de todas as partes, não se apossem, desfrutem e destruam os terrenos e matas da Aldeia" (SERGIMIRIM, 4 de nov. 1873. APEB, Seção Colonial/Provincial, Maço 4614). Em fevereiro de 1875, o diretor geral dos índios, tendo sido informado que parte dos terrenos dos índios tinha sido esbulhado e que precisava nomear um diretor que advogasse o interesse dos indígenas, pediu a exoneração de Antônio Rodrigues do cargo e foi nomeado Manoel Pereira dos Santos (TANAJURA, 1 de dez. 1873; SERGIMIRIM, 23 de fev. 1875. APEB, Seção Colonial/Provincial, Maço 4614).

Em maio de 1877, Manoel Joaquim Dias Monteiro e outros moradores de Pedra Branca pediram ao governo provincial a demissão do diretor Manoel Pereira dos Santos e a nomeação do capelão padre Vigário Leovigildo José da Silva Freire. Os moradores 
motivaram o pedido alegando que Manoel não residia na freguesia, mas em Curralinho, de tal modo que não cuidava dos índios e estava se apossando das rendas das terras (MONTEIRO 12 de set. 1877. APEB, Seção Colonial/Provincial, Maço 4613; MONTEIRO, 19 de fev. 1878; APEB, Seção Colonial/Provincial, Maço 4614). Diante das acusações, o diretor geral dos índios não quis propor logo a demissão de Manoel Pereira, porque queria certificar-se das denúncias, pois dizia serem elas feitas pelos rendeiros dos terrenos da aldeia onde habitavam poucos índios, terrenos que estavam sendo investidos pela grande ambição de particulares por serem muito férteis e terem abundante e excelente água (SERGIMIRIM, 19 de mar. 1878. APEB, Seção Colonial/Provincial, Maço 4614). Persistindo os pedidos de demissão do diretor, um ano depois dos primeiros pedidos, foi nomeado o padre Leovigildo José da Silva Freire. Voltava, portanto, à diretoria dos índios a um sacerdote e seria o último diretor nomeado para Pedra Branca (SERGIMIRIM, 10 de mai. 1878. APEB, Seção Colonial/Provincial, Maço 4614; GOMES, 5 de abr. 1881. APEB, Seção Colonial/Provincial, Maço 4613).

\section{Extinção do aldeamento de Pedra Branca}

As informações concernentes a Pedra Branca na década de 1880 são raras. Em janeiro de 1885, a Secretaria de Estado dos Negócios da Agricultura pediu ao governo provincial que desse as providências convenientes, segundo as leis, ${ }^{7}$ a respeito das terras do extinto aldeamento de Pedra Branca, que estavam ocupadas por indivíduos sem título legítimo. Mas o ato da Presidência da província de extinção da aldeia é de 31 de junho de 1885. Em 3 de setembro do mesmo ano, o governo nomeou Baldoino Nunes de Queirós como conservador dos terrenos da extinta aldeia. Naquela ocasião, o conservador estava promovendo um alistamento dos índios, para conhecer seu número, sua ascendência e descendência, qual o terreno que ocupavam e suas benfeitorias (SECRETÁRIA DE ESTADO DOS NEGÓCIOS DA AGRICULTURA, COMERCIO E OBRAS PÚBLICAS, 10 de jul. 1885; QUEIRÓS, 29 de set. 1885. APEB, Seção Colonial/Provincial, Maço 4614). Não temos notícias do resultado do trabalho do conservador, mas em novembro de 1889, o Ministério dos Negócios da Agricultura ainda pedia informação sobre a área aproximada do extinto aldeamento e se suas terras se prestavam ou não para o

\footnotetext{
${ }^{7}$ As leis invocadas pela Secretária eram a Lei ${ }^{\circ} 601$ de 18 de setembro de 1850; o artigo 88 do Regulamento de 30 de janeiro de 1854; o Aviso de 21 de julho de 1858; o artigo 11 da Lei ${ }^{\circ} 1114$ de 27 de setembro de 1860; e o Aviso de 5 de abril de 1879.
} 
estabelecimento de imigrantes (MINISTÉRIO DOS NEGÓCIOS DA AGRICULTURA, COMÉRCIO E OBRAS PÚBLICAS, Rio de Janeiro, 14 de nov. 1889. APEB, Seção Colonial/Provincial, Maço 783-1).

\section{Conclusão}

A complexidade dos acontecimentos, o emaranhado das relações entre os diversos atores em cena, o caráter da documentação utilizada, muitas vezes imbuída de interesses particulares, parcialidades e exageros, requer muita atenção do historiador para não chegar a conclusões apressadas e injustas. Dito isso, apontamos, a modo de conclusão, alguns pontos que podem explicar os motivos dos conflitos e o processo que levou a supressão da municipalidade da vila de Pedra Branca e sua volta à categoria de aldeamento, o processo de usurpação das terras indígenas, a dispersão dos indígenas e a supressão do aldeamento.

Em primeiro lugar, é importante notar que os conflitos em Pedra Branca e em seu entorno não se deu somente entre indígenas e não indígenas, mas também entre autoridades locais, evidenciando um conflito de jurisdição e de interesses, que contribuiu para o prolongamento das disputas.

O motivo maior dos conflitos deve ser colocado nos progressivos abusos no campo da administração dos bens dos índios, principalmente o fundiário, isso, graças também à falta de clareza jurídica em matéria indigenista. Até quando em Pedra Branca funcionou a municipalidade com sua câmara de vereação, nota-se um conflito em torno da participação dos cargos públicos entre indígenas e não indígenas. Os índios reivindicavam tal participação não só porque eram a maioria, mas também porque viam nestes cargos públicos (vereadores e juízes de paz) um meio de defender seus direitos e de tomar em mãos as rédeas das suas vidas.

As políticas e as práticas das autoridades públicas no trato com os índios no período em estudo não têm muita novidade em relação ao período colonial brasileiro. Buscou-se controlar e enquadrar os indígenas numa ordem estabelecida através de meios coercitivos (expedições militares) e pacíficos (diretores leigos e religiosos), mantendo-os na velha condição de tutelados e recorrendo às leis para afirmar a não idoneidade dos índios para os cargos públicos, assim como descrevendo-os como sendo os piores criminosos, preguiçosos, incapazes, imorais e causa da falta de progresso na vila e depois aldeamento de Pedra Branca. 
Os conflitos, revoltas e as insubordinações dos índios em relação às autoridades locais narrados ao longo deste trabalho fazem parte do processo de resistência dos aldeados, em defesa principalmente do seu maior bem, a terra, que estava sendo usurpada por particulares. Nesses conflitos entre indígenas e moradores locais não indígenas, os maiores perdedores foram os primeiros, pois as decisões em relação à Pedra Branca, na tentativa de resolver os conflitos e estabelecer a ordem, além das expedições enviadas contra os "revoltosos", foram a extinção da municipalidade e depois do aldeamento. Os constantes conflitos e a progressiva usurpação das terras do aldeamento levaram a fuga, dispersão e migração dos moradores indígenas para outras localidades como o Ribeirão e o aldeamento de Santa Rosa (área do atual município de Jequié).

Enfim, de fato as terras da vila e depois aldeamento de Pedra Branca foram invadidas por particulares e muitos dos moradores indígenas se dispersaram. Isso foi resultado das políticas e das leis, assim como também da falta de clareza legal, em processo desde o período colonial. Mas esse processo não foi assim tão linear, como ficou demonstrado ao longo deste trabalho. Os indígenas tiveram atitudes e suas decisões influenciaram e condicionaram o modo de viver em Pedra Branca e em seu entorno. 


\section{Referências}

MONTEIRO, John Manoel. Tupis, Tapuias e Historiadores: Estudos de História Indígena e do Indigenismo. Campinas: Departamento de Antropologia/ IFCH-Unicamp 2001.

PARAÍSO, Maria Hilda Baqueiro. O Tempo da Dor e do Trabalho: a Conquistas dos Territórios Indígenas nos Sertões do Leste. São Paulo, Tese de Doutorado em História Social, Faculdade de Filosofia, Letras e Ciências Humanas, Departamento de História, USP, 1998.

PARAÍSO, Maria Hilda Baqueiro. Os Kiriri Sapuyá de Pedra Branca. Salvador: Centro de Estudos Baianos, 1985.

REGO, André de Almeida. Cabilda de facinorosos moradores: uma reflexão sobre a revolta dos índios da Pedra Branca de 1834. 2009. Dissertação (Mestrado em História Social) - Faculdade de Filosofia e Ciências Humanas, Universidade Federal da Bahia, Salvador. Disponível em: https://repositorio.ufba.br/ri/bitstream/ri/12189/1/cabilda\%20de\%20facinorosos\%20mor adores.pdf . Acesso em: 29 jun. 2019.

SANTOS, Fabricio Lyrio. Da catequese à civilização: colonização e povos indígenas na Bahia (1750-1800). 2012. Dissertação (Mestrado em História Social) - Faculdade de Filosofia e Ciências Humanas, Universidade Federal da Bahia, Salvador. Disponível em: https://repositorio.ufba.br/ri/bitstream/ri/11613/1/SANTOS\%2c\%20Fabricio\%20Lyrio $\% 20-\% 20 \mathrm{Da} \% 20$ catequese $\% 20 \%$ c3\%a0\%20civiliza\%c3\%a7\%c3\%a30.pdf. Acesso em: 29 jun. 2019.

\section{Fontes arquivísticas (manuscritos)}

ABAIXO-ASSINADO DOS MORADORES DA TAPERA. [Correspondência]. Destinatário: Antônio Inácio de Azevedo (presidente da Província). Freguesias de Nossa Senhora da Conceição da Tapera, 3 de mar. 1847. APEB, Seção Colonial/Provincial, Maço 4611.

ABAIXO-ASSINADO SOBRE LUIZ CARLOS DA SILVEIRA. [Correspondência]. [s.d.]. Pedra Branca, 21 de fev. 1848. APEB, Seção Colonial/Provincial, Maço 4611.

ALBUQUERQUE, Albino A. de Novais (juiz municipal e delegado). [Correspondência]. Destinatário: Francisco Gonçalves Martins (presidente da Província). Tapera, [s.d.] de mai. 1867. APEB, Seção Colonial/Provincial, Maço 2614.

ALMEIDA, Tomaz Garcia de. [Correspondência]. [s.d.]. Palácio do Governo da Bahia, jul. 1838. APEB, Seção Colonial/Provincial, Maço 4613.

ANDRADE, Antônio Caetano de (juiz municipal). [Correspondência]. Destinatário: Joaquim José Pinheiro de Vasconcelos (presidente da Província). Pedra Branca, 5 de mar. 1835. APEB, Seção Legislativa, Série Ofícios Recebidos e Expedidos, Maço 1130.

ANDRADE, Antônio Dias de Oliveira e (Diretor dos índios de Pedra Branca). [Correspondências]. Destinatário: Antônio Inácio de Azevedo (presidente da Província). Freguesia da Pedra Branca, 7 de jan. 1846; Fazenda do Curralinho, 3 de fev. 1846. APEB, Seção Colonial/Provincial, Maço 4611.

ANDRADE, José Soares da Silva. [Correspondência]. Destinatário: Manoel Joaquim de Sá Requião. [s.l.], 5 de mar. 1841. APEB, Seção Colonial/Provincial, Maço 2530. 
ANDRADE, José Soares da Silva. [Correspondência]. Destinatário: Paulo de Mello Britto. Pedra Branca, 6 de mar. 1841. APEB, Seção Colonial/Provincial, Maço 2530.

BAHIA, Manoel Joaquim (juiz de direito). [Correspondências]. Destinatário: João Maurício Wanderley (presidente da Província). Nazaré, 7 de jan. 1853; 13 de jan. 1853. APEB, Seção Colonial/Provincial, Maço 2505.

BARRETO, Pedro Tales (juiz de paz). [Correspondência]. Destinatário: Francisco de Souza e Martins (presidente da Província). Vila da Pedra Branca, 16 de fev. 1835. APEB, Seção Colonial/Provincial, Maço 2530.

BERLINK, Joaquim Pedro (capitão comandante do destacamento). [Correspondências]. Destinatário: Joaquim José Pinheiro de Vasconcelos (presidente da Província). Pedra Branca, 12 de set. 1834; Pedra Branca, 13 de set. 1834. APEB, Seção Colonial/Provincial, Maço 2861.

BRITO, Antônio Ferreira de (diretor dos índios de Pedra Branca). [Correspondência]. Destinatário: João Carneiro Rego (presidente da Província). Pedra Branca, 30 de out. 1839. APEB, Seção Colonial/Provincial, Maço 4611.

BRITO, José Simões de (diretor dos índios). [Correspondência]. Destinatário: Joaquim de Vasconcelos (presidente da Província). Pedra Branca, 20 de out. 1842. APEB, Seção Colonial/Provincial, Maço 4611.

BRITO, José Simões de (diretor dos índios); CRUZ, Frutuoso Pereira da (juiz de paz). [Correspondência]. Destinatário: Joaquim de Vasconcelos (presidente da Província). Pedra Branca, 7 de out. 1842. APEB, Seção Colonial/Provincial, Maço 2530.

CÂMARA MUNICIPAL DA VILA DE NAZARÉ. [Correspondência]. Destinatário: Francisco Vicente Viana (presidente da Província). Vila de Nazaré, 30 de abr. 1825. APEB, Seção Colonial/Provincial, Maço 1376.

CÂMARA MUNICIPAL DE CACHOEIRA. [Correspondência]. Destinatário: Paulo de Mello Britto (presidente da Província). Cachoeira, 25 de jan. 1841. APEB, Seção Colonial/Provincial, Maço 1270.

CÂMARA MUNICIPAL DE PEDRA BRANCA. [Correspondência]. Destinatário: José Egídio Gordilho (presidente da Província). Pedra Branca, 28 de ago. 1828. APEB, Seção Colonial/Provincial, Maço 1376.

CÂMARA MUNICIPAL DE PEDRA BRANCA. [Correspondências]. Destinatário: Joaquim de Vasconcelos (presidente da Província). Pedra Branca, 22 de jul. 1834; Pedra Branca, 8 de ago. 1833. APEB, Seção Colonial/Provincial, Maço 1376.

CASARANO, Agostinho de (missionário e diretor dos índios de Pedra Branca). [Correspondência]. Destinatário: João Maurício Wanderley (presidente da Província). Pedra Branca, 14 de mar. 1853. APEB, Seção Colonial/Provincial, Maço 5308.

CASARANO, Agostinho de (vigário e missionário). [Correspondência]. Destinatário: Delegado da Repartição Especial das Terras Públicas da Bahia. Aldeia da Pedra Branca, 3 de nov. 1857. APEB, Seção Colonial/Provincial, Maço 6508.

CASSARANO, Agostinho de (missionário e diretor de índio de Pedra Branca). Pedra Branca, 7 de jan. 1848. APEB, Seção Colonial/Provincial, Maço 4611.

CASTRO, José Antônio da Silva (major). [Correspondências]. Destinatário: Joaquim José Pinheiro de Vasconcellos (presidente da Província). São Félix, 20 de mai. 1834; São Felix, 6 de set. 1834; Acampamento da Vila da Pedra Branca, 6 de jun. 1834; 
Acampamento da Vila da Pedra Branca, 13 jun. 1834; Pedra Branca, 24 jun. 1834. APEB, Seção Colonial/Provincial, Maço 2861; Acampamento da Vila da Pedra Branca, 6 de jun. 1834. Seção Colonial/Provincial, Maço 2861.

COSTA, Manuel Vieira. [Correspondência]. Destinatário: Joaquim José Pinheiro de Vasconcellos (presidente da Província). Curralinho, 26 de ago. 1834. APEB, Seção Colonial/Provincial, Maço 4611.

DORIA, José Jacome (diretor geral dos índios). [Correspondência]. Destinatário: Francisco Xavier Pais Barreto (presidente da Província). Bahia, 29 de mar. 1859. APEB, Seção Colonial/Provincial, Maço 4612.

FALERNA, Francisco Antônio de. [Correspondência]. Destinatário: João Maurício Wanderley (presidente da Província). Rio de Contas, 26 de dez. 1853. APEB, Seção Colonial/Provincial, Maço 4611.

GALVÃO, José Rocha (comandante de tropa). [Correspondência]. Destinatário: José Antônio da Silva Castro (major). Pedra Branca, 2 de jul. 1834. APEB, Seção Colonial/Provincial, Maço 2861.

GALVÃO, Manoel Rocha (Delegado do Termo da cidade de Cachoeira). [Correspondência]. [s.d.]. Fazenda das Boatas na Vila da Tapera, 2 de jan. 1851. APEB, Seção Colonial/Provincial, Maço 5308.

GOMES, José Caetano (procurador). [Correspondência]. Destinatário: João Lustosa Paranaguá (presidente da Província). Bahia, 5 de abr. 1881. APEB, Seção Colonial/Provincial, Maço 4613.

GUEDES, Francisco de Oliveira (juiz municipal interino) [Correspondências]. Destinatário: Joaquim José Pinheiros de Vasconcellos (presidente da Província). Fazenda da Tapera, 21 de abr. 1834; Fazenda da Tapera, 12 de abr. 1834. APEB, Seção Colonial/Provincial, Maço 2614.

ICÓ, Antônio Péricles Souza (juiz de paz). [Correspondência]. Destinatário: Antônio Inácio de Azevedo (presidente da Província). Freguesia de Conceição da Tapera, 17 de fev. 1847. APEB, Seção Colonial/Provincial, Maço 2614.

ICÓ, Antônio Péricles Souza (juiz municipal). [Correspondências]. Destinatário: João Maurício Wanderley (presidente da Província). Tapera, 3 de jan. 1853; Tapera, 4 de jan. 1853; Tapera, 8 de jan. 1853; Tapera, 31 de jan. 1853; Tapera, 14 mar. 1853. APEB, Seção Colonial/Provincial, Maço 2614.

ICÓ, Antônio Péricles Souza (juiz municipal). [Correspondência]. Destinatário: João Luís Vieira Cansanção (presidente da Província). Tapera, 21 de jan. 1858. APEB, Seção Colonial/Provincial, Maço 2614.

ICÓ, Antônio Péricles Souza (juiz municipal). [Correspondência]. Destinatário: Francisco Xavier Paes (presidente da Província). Tapera, 11 de mar. 1859. APEB, Seção Colonial/Provincial, Maço 2614.

SILVEIRA, Luiz Carlos da (diretor de índios de Pedra Branca). Relação de ferramentas. Pedra Branca, 6 de out. 1847. APEB, Seção Colonial/Provincial, Série Agricultura $\mathrm{N}^{\circ}$ Maço 4611.

ÍNDIOS DA VILA DE PEDRA BRANCA. [Correspondência]. Destinatário: José Antônio da Silva Castro (major). Vila de Pedra Branca, 27 de mai. 1834. APEB, Seção Colonial/Provincial, Maço 4611. 
ÍNDIOS HABITANTES NA PEDRA BRANCA (assinada por 27 pessoas). [Correspondência]. Destinatário: Manoel Ignácio de Lima (diretor Geral dos índios). Pedra Branca, [s.d.]. APEB, Seção Colonial/Provincial, Maço 4611.

JESUS, Feliciano. [Correspondência]. Destinatário: Trasibulo da Rocha Passos (chefe de Polícia da Província). Pedra Branca, 20 de jun. 1859. APEB, Seção Colonial/Provincial, Maço 4612.

LIMA, Manoel Ignácio de (diretor Geral dos Índios). [Correspondências]. Destinatário: Antônio Ignácio de Azevedo (presidente da Província). Iguape, 2 de jan. 1847; Iguape, 4 de jan. 1847; Bahia, 28 de mar. 1847; Iguape, 2 de jul. 1847; Bahia, 3 de set. 1847. APEB, Seção Colonial/Provincial, Maço 4611.

LIMA, Manoel Ignácio de (diretor geral dos índios). [Correspondências]. Destinatário: João José Moura Magalhães (presidente da Província). Bahia, 13 de out. 1847; Bahia, 21 de nov. 1847; Iguape, 12 jan. 1848; Bahia, 27 de fev. 1848. APEB, Seção Colonial/ Provincial, Maço 4611.

LIMA, Manoel Ignácio de (diretor geral dos índios). [Correspondências]. Destinatário: a Francisco Gonçalves Martins (presidente da Província). Bahia, 18 de jan. 1849; Bahia, 28 de abr. 1849. APEB, Seção Colonial/Provincial, Maço 4611.

LUIZ, João Ferreira (Chefe de polícia interino). [Correspondência]. [s.d.]. Cachoeira, 6 de jun. 1851. APEB, Seção Colonial/Provincial, Maço 5308.

MADUREIRA, Casemiro de Sena (diretor geral dos índios). [Correspondência]. Destinatário: Francisco Gonçalves Martins (presidente da Província). Bahia, 21 de mar. 1850. APEB, Seção Colonial/Provincial, Série Maço 4611.

MADUREIRA, Casemiro de Sena (diretor geral dos índios). [Correspondência]. Destinatário: Álvaro Tibério de Moncorvo e Lima (vice-presidente da Província). Bahia, 18 de jul. 1850. APEB, Seção Colonial/Provincial, Maço 4611.

MADUREIRA, Casemiro de Sena (diretor geral dos índios). [Correspondência]. Destinatário: João Maurício Wanderley (presidente da Província). Bahia, 3 de out. 1854. APEB, Seção Colonial/Provincial, Maço 4612.

MADUREIRA, Casemiro de Sena. Relatório do Diretor Geral dos índios de 22 de jan. 1851, p. 3. Anexo à Falla do Presidente da província da Bahia, Francisco Gonçalves Martins, Bahia, 1851.

MADUREIRA, Casemiro de Sena. Relatório do Diretor Geral dos índios de 19 de fev. 1852, p. 3. Anexo na Falla do Presidente da Província da Bahia, Francisco Gonçalves Martins, Bahia, 1852.

MADUREIRA, Casimiro de Sena (diretor geral dos índios). [Correspondências]. Destinatário: Francisco Gonçalves Martins (presidente da Província). Bahia, 31 de mar. 1851; Bahia, 1 de mar. 1851. APEB, Seção Colonial/Provincial, Maço 4611.

MADUREIRA, Casimiro de Sena (diretor geral dos Índios). [Correspondência]. Destinatário: Álvaro Tibério de Moncorvo e Lima (vice-presidente da Província). Bahia, 6 de jun. 1851. APEB, Seção Colonial/Provincial, Maço 4611.

MADUREIRA, Casimiro de Sena (diretor geral dos índios). [Correspondência]. Destinatário: Manoel Messias de Leão (vice-presidente da Província). Bahia, 18 de mai. 1858. APEB, Seção Colonial/Provincial, Maço 4612. 
MAPA DAS ALDEIAS DA PROVÍNCIA DA BAHIA. 9 de fev. 1855. APEB, Seção Colonial/Provincial, Maço 4613.

MAPA DAS ALDEIAS INDÍGENAS DA PROVÍNCIA DA BAHIA, apresentado pelo Diretor Geral dos Índios, José Jácomo Dórea. 14 de jan. 1861. APEB, Seção Colonial/Provincial, Maço 4610.

MAPA DO MUNICÍPIO DE TAPERA, 1872. APEB, Seção Colonial/Provincial, Maço 1445.

MEDRADE, Francisco José da Rocha. [Correspondência]. Destinatário: Francisco Gonçalves Martins (presidente da Província). Vila de Santa Isabel, 15 de out. 1870. APEB, Seção Colonial/Provincial, Maço 4614.

MEDRADO, José Egídio da Rocha (juiz de paz da Tapera). [Correspondências]. Destinatário: José Antônio da Silva Castro (major). Pedra Branca, 22 de jun. 1834. APEB, Seção Colonial/Provincial, Maço 2861. Tapera, 28 de mai. 1834. APEB, Seção Colonial/Provincial, Maço 4611.

MINISTÉRIO DOS NEGÓCIOS DA AGRICULTURA, COMÉRCIO E OBRAS PÚBLICAS. [Ofício]. Destinatário: José Luís de Almeida Couto (presidente da Província). Rio de Janeiro, 14 de nov. 1889. APEB, Seção Colonial/Provincial, Maço 783-1.

MIRANDA, Antônio José de ( $2^{\circ}$ Sargento Comandante da Força). [Correspondência]. [s.d.]. Folha do Buraco, 12 de set. 1848. APEB, Seção Colonial/Provincial, Maço 4611.

MONTEIRO, Manoel Joaquim Dias. [Correspondência]. [s.d.]. Pedra Branca, 19 de fev. 1878; APEB, Seção Colonial/Provincial, Maço 4614.

MONTEIRO, Manoel Joaquim Dias. [Correspondência]. Destinatário: Henrique Pereira de Lucena (presidente da Província). Pedra Branca, 12 de set. 1877. APEB, Seção Colonial/Provincial, Maço 4613.

OLIVEIRA, Benigno Tavares de (juiz municipal e delegado). [Correspondência]. Destinatário: Antônio Inácio de Azevedo (presidente da Província). Nazaré, 4 de fev. 1847. APEB, Seção Colonial/Provincial, Maço 2504.

OLIVEIRA, Luiz José de. [Correspondência]. Destinatário: José Egídio Gordilho (presidente da Província). Pedra Branca, 9 de jul. 1830. APEB, Seção Colonial/Provincial, Maço 1376.

OLIVEIRA, Manole (juiz municipal). [Correspondência]. Destinatário: João Maurício Wanderley (presidente da Província). Tapera, 8 de jan. 1853. APEB, Seção Colonial/Provincial, Maço 2614.

OLIVEIRA. Frutuoso José de (diretor dos índios de Pedra Branca). [Correspondências]. Destinatário: Antônio Inácio de Azevedo (presidente da Província). Pedra Branca, 20 mai. 1846. APEB, Seção Colonial/Provincial, Maço 4611. Pedra Branca, 3 de set. 1846. APEB, Seção Colonial/Provincial, Maço 4613.

OLIVEIRA. Frutuoso José de (diretor dos índios de Pedra Branca). [Correspondência]. Destinatário: Antônio Inácio de Azevedo (presidente da Província). Pedra Branca, 3 de set. 1846. APEB, Seção Colonial/Provincial, Maço 4613.

OVADA, Rainero de (missionário e diretor dos índios de Pedra Branca). [Correspondência]. Destinatário: Herculano Ferreira Pena (presidente da Província). Aldeia da Pedra Branca, 21 set. 1859. APEB, Seção Colonial/Provincial, Maço 4612. 
OVADA, Rainero de (missionário e diretor dos índios de Pedra Branca). [Correspondências]. [s.d]. Pedra Branca, 20 de ago. 1859. APEB, Seção Colonial/Provincial, Maço 4612. Pedra Branca, 20 de dez. 1860. APEB, Seção Colonial/Provincial, Maço 6509.

PARANAGUÁ, João Lustosa (delegado). [Correspondência]. Destinatário: João Maurício Wanderley (presidente da Província). Vila da Cachoeira, 9 de jan. 1853. APEB, Seção Colonial/Provincial, Maço 2991.

PARANAGUÁ, João Lustosa (delegado). [Correspondências]. Destinatário: André Corsino Pinto C. da Gama (chefe de polícia da província). Vila da Tapera, 22 de jan. 1853; Vila da Tapera, 26 de jan. 1853. APEB, Seção Colonial/Provincial, Maço 4611.

PASSOS, Trasibulo de Rocha (delegado). [Correspondência]. Destinatário: Antônio Joaquim da Silva Gomes (presidente da Província). Cachoeira, 23 de abr. 1864. APEB, Seção Colonial/Provincial, Maço 2994.

PETRALIA, Serafim de (missionário e Diretor de índios de Pedra Branca). [Correspondências]. Destinatário: Casimiro de Sena Madureira (diretor geral dos índios). Pedra Branca, 23 de mar. 1851; Pedra Branca, 24 de mar. 1851; Pedra Branca, 7 de jul. 1850. APEB, Seção Colonial/Provincial, Maço 4611.

PETRALIA, Serafim de (missionário e diretor dos Índios de Pedra Branca). [Correspondência]. Destinatário: Álvaro Tibério de Moncorvo e Lima (vice-presidente da Província). Pedra Branca, 24 de mai. 1851. APEB, Seção Colonial/Provincial, Maço 5308.

PINTO, Carlos de Cerqueira (chefe de polícia interino). [Correspondência]. Destinatário: Barão de S. Lourenço (presidente da Província). Secretaria da polícia da província da Bahia, 18 de jan. 1871. APEB, Seção Colonial/Provincial, Maço 4614.

PITTA, Manoel Glória (vigário e diretor de Pedra Branca). [Correspondência]. Destinatário: Francisco Gonçalves Martins (presidente da Província). Pedra Branca, 9 de ago. 1868. APEB, Seção Colonial/Provincial, Maço 5313.

QUEIRÓS, Baldoino Nunes de. [Correspondência]. Destinatário: José de Almeida Couto (presidente da Província). Freguesia da Pedra Branca, 29 de set. 1885. APEB, Seção Colonial/Provincial, Maço 4614.

REGULAMENTO PARA A ADMINISTRAÇÃO DOS BENS DOS ÍNDIOS DA PEDRA BRANCA, Bahia, 20 de jun. 1836. APEB, Seção Colonial/Provincial, Maço 4611.

RELATÓRIO DA CÂMARA DA VILA DE CONCEIÇÃO DA TAPERA. [Correspondência]. Destinatário: Francisco Gonçalves Martins (presidente da Província). Tapera, 15 de fev. 1851. AHNSP, Caixa Ea 4, Missões.

ROCHA, Antônio L. de Figueiredo. [Correspondência]. Destinatário: Manoel Messias de Leão (vice-presidente da Província). Repartição da polícia da Bahia, 25 de jul. 1859. APEB, Seção Colonial/Provincial, Maço 4612.

ROCHA, Torquato Rodrigues de Ultra (delegado das Terras Públicas). [Correspondência]. Destinatário: Vigário de Pedra Branca. Bahia, 29 de jan. 1858. APEB, Seção Colonial/Provincial, Maço 7030.

SAMPAIO, Antônio Vieira (delegado). [Correspondência]. Destinatário: Chefe de polícia da província da Bahia. Vila da Tapera, 20 de dez. 1870. APEB, Seção Colonial/Provincial, Maço 4614. 
SAMPAIO, Antônio Vieira (juiz suplente). [Correspondência]. Destinatário: José Antônio da Silva Castro (major). Jiboia, 30 jul. 1834. APEB, Seção Colonial/Provincial, Maço 2861.

SAMPAIO, Joaquim José (subdelegado). [Correspondência]. Destinatário: Manoel Ignácio de Lima (Diretor Geral dos Índios). Freguesia de São Miguel, 1 de jan. 1847. APEB, Seção Colonial/Provincial, Maço 4611.

SANTOS, José Henrique dos (juiz de paz). [Correspondência]. Destinatário: Joaquim José Pinheiro de Vasconcellos (presidente da província). Vila da Pedra Branca, 23 abr. 1834. APEB, Seção Colonial/Provincial, Maço 2530;

SANTOS, José Henrique dos (juiz de paz). [Correspondência]. Destinatário: José Antônio da Silva Castro (major). Pedra Branca, 23 de jun. 1834. APEB, Seção Colonial/Provincial, Maço 2861.

SANTOS, Manoel de Souza. [Correspondência]. Destinatário: José Egídio Gordilho (presidente da Província). Pedra Branca, 20 de jan. 1829. APEB, Seção Colonial/Provincial, Maço 5213.

SECRETÁRIA DE ESTADO DOS NEGÓCIOS DA AGRICULTURA, COMERCIO E OBRAS PÚBLICAS. [Correspondência]. Destinatário: José de Almeida Couto (presidente da Província). Rio de Janeiro, 10 de jul. 1885. APEB, Seção Colonial/Provincial, Maço 4614.

SEIXAS, Romualdo Antônio de (arcebispo da Bahia). [Correspondência]. Destinatário: Francisco José de Sousa Soares de Andréa (presidente da Província). Bahia, 22 de abr. 1846. APEB, Seção Legislativa, Série Ofícios Recebidos e Expedidos, Maço 1140.

SEIXAS, Romualdo Antônio de (arcebispo da Bahia). [Correspondência]. Destinatário: João José de Moura Magalhães (presidente da Província). Bahia, 22 de jan. 1848. APEB, Seção Colonial/Provincial, Maço 5205.

SEIXAS, Romualdo Antônio de (arcebispo da Bahia). [Correspondência]. Destinatário: Manoel Messias de Leão (vice-presidente da Província). Bahia, 20 de mai. 1858. APEB, Seção Colonial/Provincial, Maço 5203.

SERGIMIRIM, Barão de (diretor geral dos índios). [Correspondência]. Destinatário: Francisco Gonçalves Martins (presidente da Província). Bahia, 12 de jan. 1871. APEB, Seção Colonial/Provincial, Maço 4614.

SERGIMIRIM, Barão de (diretor geral dos índios). [Correspondência]. Destinatário: Francisco José de Rocha (presidente da Província). Bahia, 7 de jul. 1871. APEB, Seção Colonial/Provincial, Maço 4614.

SERGIMIRIM, Barão de (diretor Geral dos Índios). [Correspondência]. Destinatário: Antônio Cândido da Cruz (presidente da Província). Bahia, 4 de nov. 1873. APEB, Seção Colonial/Provincial, Maço 4614.

SERGIMIRIM, Barão de (diretor geral dos índios). [Correspondência]. Destinatário: Venâncio José de Oliveira Lisboa (presidente da Província). Bahia, 23 de fev. 1875. APEB, Seção Colonial/Provincial, Maço 4614.

SERGIMIRIM, Barão de (diretor geral dos índios). [Correspondências]. Destinatário: Barão Homem de Mello (presidente da Província). Bahia, 10 de mai. 1878. APEB, Seção Colonial/Provincial, Maço 4614. 
SERGIMIRIM, Barão de (diretor geral dos índios). [Correspondências]. Destinatário: Barão Homem de Mello (presidente da Província). Engenho Europa (no Bom Jardim em Santo Amaro), 19 de mar. 1878. APEB, Seção Colonial/Provincial, Maço 4614.

SILVA, Antônio Moniz Barreto da (delegado $1^{\mathrm{o}}$ suplente). [Correspondências]. Destinatário: João Maurício Wanderley (presidente da Província). Nazaré, 4 de jan. 1853; Nazaré, 8 de jan. 1853; Nazaré, 16 de jan. 1853. APEB, Seção Colonial/Provincial, Maço 2991.

SILVA, Antônio Moniz Barreto da (delegado). [Correspondência]. Destinatário: Álvaro Tibério de Moncorvo e Lima (presidente da Província). Vila da Tapera, 8 de out. 1855. APEB, Seção Colonial/Provincial, Maço 2992.

SILVA, Joaquim da. [Correspondência]. Destinatário: Joaquim José Pinheiro de Vasconcelos (presidente da Província). Acampamento da Vila da Pedra Branca, 22 de jun. 1834. APEB, Seção Colonial/Provincial, Maço 2861.

SILVA, Joaquim da; PEREIRA, José; LIMA, Firmino Mendes. [Correspondência]. Destinatário: José Antônio da Silva Castro (major). Pedra Branca, 4 de jul. 1834. APEB, Seção Colonial/Provincial, Maço 2861.

SILVA, Joaquim Simões Daltro e (juiz municipal e delegado). [Correspondências]. Destinatário: Francisco José da Rocha (presidente da Província). Tapera, 25 de abr. 1871; Tapera, 4 de abr. 1871; Tapera, 5 de mar. 1871. APEB, Seção Colonial/Provincial, Maço 2614.

SILVA, Luiz Carlos da (diretor dos índios da Pedra Branca). [Correspondências]. Destinatário: Manoel Ignácio de Lima (diretor geral dos índios). Pedra Branca, 24 de mai. 1847; Cachoeira, 26 de fev. 1848; Pedra Branca, 8 de jun. 1847; Pedra Branca, 24 de ago. 1847; Pedra Branca, 7 de jan. 1848. APEB, Seção Colonial/Provincial, Maço 4611.

SILVEIRA, Luiz Carlos da (tenente coronel e diretor dos índios de Pedra Branca). [Correspondência]. Destinatário: Manoel Ignácio de Lima (diretor geral dos índios). Pedra Branca, 18 de jul. 1847. APEB, Seção Colonial/Provincial, Maço 4611.

SILVEIRA, Manuel Joaquim da (Arcebispo da Bahia). [Correspondência]. Destinatário: Antônio Coelho de Sá e Albuquerque (presidente da Província). Residência Arquiepiscopal da Penha, 22 de jan. 1863. APEB, Seção Colonial/Provincial, Maço 5204.

SOUZA, Cirilo Alexandrino de Oliveira e (vigário e diretor dos índios de Pedra Branca). [Correspondências]. Destinatário: Barão de S. Lourenço (presidente da Província). Pedra Branca, 24 de mar. 1869; Pedra Branca, 18 de nov. 1870; Pedra Branca, 04 de mar. 1871. APEB, Seção Colonial/Provincial, Maço 4614.

TANAJURA, Antônio Roiz de Aquino (diretor dos índios de Pedra Branca). [Correspondência]. Destinatário: Antônio Cândido da Cruz Machado (presidente da província). Aldeia da Pedra Branca, 1 de dez. 1873. APEB, Seção Colonial/Provincial, Maço 4614.

VERMELHO, Barão do Rio (diretor geral dos índios). [Correspondência]. Destinatário: Pedro Leão Vellozo (vice-presidente da Província). Bahia, 30 de jul. 1866. APEB, Seção Colonial/Provincial, Maço 4614.

VERMELHO, Barão do Rio (diretor geral dos índios). [Correspondência]. [s.d.]. Bahia, 27 de fev. 1869. APEB, Seção Colonial/Provincial, Maço 4614. 